\title{
Long-Term Effects of Amendment with Olive Mill Wastewater on Soil Chemical Properties, Microbial Community, and Olive Tree Vegetative and Productive Activities
}

\author{
Luca Regni ${ }^{1,+}$, , Daniela Pezzolla ${ }^{2,+}$, Simona Ciancaleoni ${ }^{1,+}{ }^{,}$Giorgio Marozzi ${ }^{1}$, Emidio Albertini ${ }^{1,3} \mathbb{C}$, \\ Giovanni Gigliotti ${ }^{2, *}$ (i) and Primo Proietti ${ }^{1}$ (D) \\ 1 Department of Agricultural, Food and Environmental Sciences, University of Perugia, Borgo XX Giugno, \\ 74-06121 Perugia, Italy; luca.regni@unipg.it (L.R.); simona.ciancaleoni@gmail.com (S.C.); \\ jorge2388@gmail.com (G.M.); emidio.albertini@unipg.it (E.A.); primo.proietti@unipg.it (P.P.) \\ 2 Department of Civil and Environmental Engineering, University of Perugia, Via G. Duranti, \\ 93-06125 Perugia, Italy; daniela.pezzolla@unipg.it \\ 3 Consorzio Interuniversitario per le Biotecnologie (CIB), University of Perugia, Piazza Università, \\ 1-06123 Perugia, Italy \\ * Correspondence: giovanni.gigliotti@unipg.it; Tel.: +39-075-585-3621 \\ + Authors contributed equally to this work.
}

Citation: Regni, L.; Pezzolla, D.; Ciancaleoni, S.; Marozzi, G.; Albertini, E.; Gigliotti, G.; Proietti, P. Long-Term Effects of Amendment with Olive Mill Wastewater on Soil Chemical Properties, Microbial Community, and Olive Tree Vegetative and Productive Activities. Agronomy 2021, 11, 2562. https://doi.org/10.3390/ agronomy11122562

Academic Editor: Claudio Ciavatta Martina Mazzon and Jose Beltrao

Received: 31 October 2021

Accepted: 9 December 2021

Published: 16 December 2021

Publisher's Note: MDPI stays neutral with regard to jurisdictional claims in published maps and institutional affiliations.

Copyright: (C) 2021 by the authors. Licensee MDPI, Basel, Switzerland. This article is an open access article distributed under the terms and conditions of the Creative Commons Attribution (CC BY) license (https:// creativecommons.org/licenses/by/ $4.0 /$ )

\begin{abstract}
The long-term effects of the olive mill wastewater (OMWW) spreading on soil chemical properties, microbial community, and olive tree parameters have been far poorly investigated. Therefore, this study aims to evaluate the effect of OMWW application on an olive orchard, and samples were collected at two different depths $(0-20 \mathrm{~cm}$ and $20-40 \mathrm{~cm})$ and 14 days, one year and two years from the end of the OMWW spreading on soil chemical characteristics and soil microbial structures. Variations of soil chemical parameters $(\mathrm{pH}$, salinity, available $\mathrm{P}$, and waterextractable organic C) were observed particularly at 14 days after spreading at both depths. All these parameters reached similar values to the soil after two years, except for available phosphorus. Firmicutes, Proteobacteria, and Actinobacteria are the most abundant phyla: only Firmicutes were negatively affected by the OMWW spreading after 14 days, suggesting that Gram-positive bacteria were probably negatively influenced by the addition of OMWW. The abundance of bacterial taxa in the soil is restored along time, except for the decrease of Firmicutes. This evidence suggests that the OMWW spreading in the long term does not affect the endemic soil bacterial community of the olive grove, as well as leaf net photosynthesis, the olive tree vegetative activity, yield, and fruits characteristics.
\end{abstract}

Keywords: olive mill wastewater; soil nutrients; microbial community; metagenomic analysis; olive tree groves amendment

\section{Introduction}

The olive oil extraction requires a considerable amount of water and produces vast quantities of oil mill wastes (OMW) in a limited period with a significant environmental impact [1-5]. The type of OMW produced depends on the extraction system adopted. Indeed, the OMW from the three-phase centrifugation is solid pomace and olive mill wastewater (OMWW). In contrast, only a wet pomace is generated from the two-phase centrifugation oil extraction system [6-8]. The OMWW has a low oil content (about $3 \%$ ). A high water content, mainly deriving from the olive fruits (depending on their stage of ripeness, water availability, and cultivars they contain $40-50 \%$ of water), the extraction plants during the washing phase (10-15\% of the weight of the processed olives), or, in continuous systems, during the extraction phase, where a possible aqueous dilution of the paste (40-60\% of the weight of the processed olives) facilitates the extraction of oil. In the Mediterranean countries, more than $30 \times 106 \mathrm{~m}^{3}$ of OMWW are produced 
during the harvest and processing season [8]. The chemical-physical characteristics of the OMWW depend on the climatic conditions of the cultivation area, the cult, the state of ripeness of the olives, and especially the type of processing adopted [9-12]. In general, OMWW contains many organic compounds in solution in colloidal state and suspension (i.e., sugars, amino acids, tannins, organic acids, lipids, alcohols, pectins, carotenoids, and phenols) [11,12], but also a significant amounts of inorganic salts (i.e., potassium phosphates, sulphates, and chlorides) both as a soluble and insoluble fraction (carbonates and silicates, about $20 \%$ ), and mineral elements (i.e., potassium, magnesium, calcium, sodium, and iron) $[13,14]$. The amendment with OMWW could supply macronutrients ( $\mathrm{P}, \mathrm{K}$, and $\mathrm{N}$ available) and organic matter to the soil, thus limiting the use of chemical fertilizers, with related economic and environmental advantages [15-17]. In fact, since OMWW derives exclusively from the mechanical extraction process, no synthetic chemicals, additives, pathogenic microorganisms, and viruses are contained or could occur for the urban sewage [18].

On the other hand, OMWW has a high potential for pollution due to the high content of salt, organic matter, phenolic compounds (catechol, hydroxytyrosol, tyrosol, and oleuropein), oxygen with a high biological (BOD) and chemical (COD) content, and high acidity. Considering salt content, the direct diffusion of the OMWW could increase the soil's electrical conductivity (EC), with different effects on the soil depending on the quantity applied $[8,13]$. Chaari et al. [19] observed that the application of OMWW over a long period (9 years) at high doses $\left(200 \mathrm{~m}^{3} \mathrm{ha}^{-1}\right)$ caused soil salinization. Furthermore, the increase of the $\mathrm{C} / \mathrm{N}$ ratio in the soil after the application of the OMWW affects microbial activity, and then the mineralization and humification [8,17], as well as the organic substance extractable from the water (WEOM), which is well-known to be affected quantitatively and qualitatively after the addition of differently stabilized organic materials [2,20-22]. Phenolic compounds distributed in the upper soil layers by OMWW application are degraded by specific bacteria and yeasts $[13,17]$. Still, a high-dose application is a stressful condition that could reduce their activity [23]. The acidity of the OMWW temporarily affects the $\mathrm{pH}$ of the soil for a high application rate and repeated treatments, showing a buffer capacity after soil disturbances $[8,23]$. Even the long-term repeated application of OMWWs can lead to relevant changes in the chemical and biochemical parameters of the soil, but only in the first period of application [24]. However, despite the presence of potential phytotoxic compounds, the OMWWs spreading could positively affect the growth performance of wheat, maize, and olive crops $[15,16,25,26]$.

In many olive-growing countries, i.e., Italy, the agronomic use of OMWW by directly spreading in the field is a widespread method of legal disposal $[1,27,28]$. Italian Law $n$. 574/96 (Nuove Norme in Materia di Utilizzazione Agronomica delle Acque di Vegetazione e di Scarichi dei Frantoi Oleari. Gazzetta Ufficiale n. 265, 12 November 1996) integrated with Legislative decree of 6 July 2005 allows the spreading of up to 50 or $80 \mathrm{~m}^{3} \mathrm{ha}^{-1}$ year $^{-1}$ olive mill wastewater generated by the press or continuous centrifugation systems, respectively [28]. Such use has taken great interest not only because it is relatively inexpensive and easily feasible but also because it allows giving organic matter to the soil. Intensive farming is a source of soil depletion that worsens the physical, chemical, and biological soil properties, leading to degenerative phenomena, of which erosion and loss of fertility are the most prominent and worrying aspects [7]. However, the spreading in the field of OMWW should be implemented with rationality since the little stabilized organic materials may inhibit or reduce the development of crops due to (I) the presence of tannins, fatty acids, and phenols, (II) the competition for the nitrogen among the microorganisms of the soil and the roots due to a high $\mathrm{C} / \mathrm{N}$ ratio, and (III) anoxia of the roots caused by the microorganism consumption of oxygen [8,29-33]. In particular, the high concentration of polymeric phenols could have a bacteriostatic effect on microorganisms and some phytotoxic effects on cultivation. Moreover, the high content of salts and the slightly acidic reaction suggest the need to manage this waste carefully. Information on the influence of OMWW spreading in the biological activity of the soil is lacking [34]. To the best of our knowledge, few studies 
deal with the molecular characterization of the microbial communities in OMWW and their effect on the soil microbiome [5,35]. Some studies characterized microbial communities with polymerase chain reaction denaturing gradient gel electrophoresis (PCR-DGGE) and polymerase chain reaction temperature gradient gel electrophoresis (PCR-TGGE) from olive mill wastes produced by an anaerobic process of two-phase centrifugation [35-37] and from OMWW generated by two olive varieties (Olea europaea var. mastoiditis and $O$. europaea var. koroneiki), studied by $16 \mathrm{~S}$ rRNA clone libraries [35]. Tsiamis et al. [38] were also able to identify a cultivar-specific profile of bacterial communities in OMWW with a culture-dependent and -independent approach. Nowadays, next-generation sequencing (NGS), coupled with bioinformatics tools, has made it easier to analyze microbial communities on any matrix, including soils $[39,40]$. To date, few studies characterized microbial communities that inhabit the olive grove's soil with NGS technologies [41,42]. On the other hand, many studies investigated the effect of OMW on soil microorganisms using cultivation-enumeration methods and enzymatic activity [27,43-47]. According to our knowledge, only Federici et al. [2] provided evidence on the short-term modifications of olive grove soil microbial communities after OMW spreading combining chemical and molecular data.

The present work aimed to evaluate the effects of OMWW spreading on soil chemical characteristics and soil microbial structures to study the evolution and dynamics of the soil microbiome of an olive orchard over time. Moreover, the effect of the OMWW spreading on the vegetative and productive activities of the olive trees was evaluated. In particular, in this study, the OMWW was directly applied in the grooves, and the soil analysis was carried out at different depths $(0-20 \mathrm{~cm}$ and $20-40 \mathrm{~cm})$ to investigate the potential risk of leaching. This unique OMWW spreading method was adopted to facilitate its management in the study area.

\section{Materials and Methods}

\subsection{Olive Grove and Environmental Characteristics}

The trial was carried out in a thirty-year-old non-irrigated olive (Olea europea L.) grove of the cultivar Frantoio located in Central Italy near Perugia $\left(12^{\circ} 59^{\prime}\right.$ E longitude, $42^{\circ} 92^{\prime} \mathrm{N}$ latitude, about $250 \mathrm{~m}$ a.s.l.). The trees were trained to the open-center system and spaced six $\times 6 \mathrm{~m}$. The soil with a silty loam texture was managed by green cover mowing. The average temperature difference between the coldest month (January) and the hottest month (July) is $19-20^{\circ} \mathrm{C}$ (with an average diurnal thermal range of $10-11^{\circ} \mathrm{C}$ and an average annual air temperature of $13-14{ }^{\circ} \mathrm{C}$ ). Extreme temperatures were recorded in the range $-7^{\circ} \mathrm{C}$ up to $36^{\circ} \mathrm{C}$. The average yearly precipitation is $800-820 \mathrm{~mm}$, primarily concentrated in the autumn, winter, and spring. In summer, rains are very scarce, and the prolonged and frequent drought periods can negatively affect the activity of the tree [48].

\subsection{Olive Mill Wastewater, Soil Amendment, and Sampling}

The organic material was collected from a traditional three-phase oil extraction system, producing two by-products, solid olive mill waste and a liquid one. This study used the latter, commonly known as olive mill wastewater (OMWW) (Table 1). The OMWW spreading $\left(80 \mathrm{~m}^{3} \mathrm{ha}^{-1}\right.$ year $\left.^{-1}\right)$ was carried out in the groove (height $30 \mathrm{~cm}$, width $40 \mathrm{~cm}$ ) realized in the inter-raw. The OMWW spreading started when the olive tree grove was ten years old, and every two years, the OMWW was distributed in the same grooves. 
Table 1. Chemical characteristics of OMWW used in the experiment.

\begin{tabular}{cc}
\hline Parameters & OMWW \\
\hline Moisture (\%) & $87.1 \pm 0.1$ \\
Volatile solids (\%) & $94.6 \pm 0.0$ \\
pH & $5.4 \pm 0.0$ \\
EC (mS/cm) & $3.7 \pm 0.0$ \\
TOC (\%) & $48.7 \pm 3.3$ \\
TKN (\%) & $0.39 \pm 0.05$ \\
Ammonium N (\%) & $0.12 \pm 0.01$ \\
Organic N (\%) & 0.27 \\
Organic N (\% on total N) & 70 \\
WEOC (\%) & $11.2 \pm 0.0$ \\
Total P (\%) & $0.11 \pm 0.00$ \\
Total K (\%) & $0.01 \pm 0.00$ \\
\hline
\end{tabular}

All data are expressed on a dry matter basis.

Soil samples were collected simultaneously (January) in different grooves (replicates) where the OMWW was spread for 14 days, one year, and two years before. Moreover, soil samples were collected at the same time also in unamended grooves (control) that were located in an olive tree grove portion that never received OMWW. This latter portion has the same soil and olive grove characteristics as the amended one. An amount of water equivalent to the amount of OMWW distributed in the amended grooves was administered in the unamended control grooves.

Three grooves for each sampling time and unamended control were used as replicates for soil analysis. To investigate the potential risk of OMWW leaching, the samples were carried out in the groove at two depths: $0-20 \mathrm{~cm}$ and $20-40 \mathrm{~cm}$. In all the grooves, each sample was composed of three different sub-samples. This sampling technique allowed to minimize spatial variability, according to [49,50]. Air-dried soils were mixed, homogenized, and sieved at $2 \mathrm{~mm}$ mesh for chemical analyses. In contrast, the soil samples were stored in sterile plastic bags for metagenomic analyses, refrigerated at $-20^{\circ} \mathrm{C}$, and subsequently analyzed within ten days. OMWW samples were standardized for DNA extraction, removing water through lyophilization.

\subsection{OMWW Chemical Characterization}

Total solid (TS) and volatile solid (VS) contents were determined by weight loss upon drying at $105{ }^{\circ} \mathrm{C}$ in an oven for $24 \mathrm{~h}$ and at $550{ }^{\circ} \mathrm{C}$ in a muffle furnace for $24 \mathrm{~h}$, respectively. Electrical conductivity (EC) and $\mathrm{pH}$ were determined on fresh material. Total organic C content (TOC) was analyzed using the Springer-Klee wet dichromate oxidation method [51]. Total Kjeldahl N (TKN) and ammonia N were determined on the fresh sample through macro and micro Kjeldahl distillation, respectively [52]. Total organic $\mathrm{N}$ was calculated by the difference between TKN and ammonia N. Total P was measured spectrophotometrically (T70 UV/Vis PG Instruments LTD, Leicestershire, UK) after the digestion of dried sample with concentrated $\mathrm{H}_{2} \mathrm{SO}_{4} / \mathrm{HClO}_{4}$ [52]. Water-extractable organic matter (WEOM) was determined as described by Said-Pullicino et al. [21] and consisted in the water extraction of the dried sample with deionized water $(1: 20 w / v)$ for $24 \mathrm{~h}$. Then the suspension was centrifuged and filtered through a $0.45 \mu \mathrm{m}$ membrane filter. The $\mathrm{C}$ content in the water extract (WEOC) was analyzed using Pt-catalyzed, high-temperature combustion $\left(800^{\circ} \mathrm{C}\right)$ followed by infrared detection of $\mathrm{CO}_{2}$ (Analytic Jena-Analyzer multi N/C 2100S, Jena, Germany).

\subsection{Soil Chemical Analysis}

The $\mathrm{pH}$ was evaluated by a glass electrode ( $\mathrm{pH}-$ Meter Basic 20+, Crison Instruments, Barcelona, Spain) after the water extraction of soil samples $(1: 2.5 w / v)$, and the electrical conductivity (EC) was measured on saturated soil pastes by a conductive probe (Ec-Meter Basic 30+, Crison Instruments, Barcelona, Spain). Total organic C (TOC) was determined using the Walkley-Black method, available P by Olsen method [53], and cation exchange ca- 
pacity (CEC) by the magnesium sulphate method [53]. Total $\mathrm{N}$ was analyzed after Kjeldahl digestion followed by micro-Kjeldahl distillation [53]. Exchangeable elements (K, $\mathrm{Ca}$, and $\mathrm{Mg}$ ) were extracted using ammonium acetate, and the elements were analyzed by plasma emission spectrometry (ICP, Optima 2000 DV PerkinElmer, Italy Spa). Determination of water-extractable organic $C$ (WEOC) consisted in a water extraction of soil samples $(1: 10 w / v)$ for $24 \mathrm{~h}$, and the total organic $C$ in water extracts was analyzed as reported for the OMWs. The soluble organic $\mathrm{C}$ in alkaline solution (TEC) was determined as described by Ciavatta et al. [54], using $0.1 \mathrm{~N} \mathrm{NaOH}$ and $0.1 \mathrm{M} \mathrm{Na}_{4} \mathrm{P}_{2} \mathrm{O}_{7}$ solution (1:5 w/v) under N2 at $65{ }^{\circ} \mathrm{C}$ for $24 \mathrm{~h}$. The TEC content was analyzed on the supernatant, after centrifugation and filtration at $0.45 \mu \mathrm{m}$, using an elemental analyzer (Analytic Jena-Analyzer multi N/C 2100S, Jena, Germania).

Two-way analysis of variance (ANOVA) was used to compare all chemical characteristics as a function of depths $(0-20$ and $20-40 \mathrm{~cm})$ and experimental time; significant differences were assessed by Tukey's Honest significant difference (HSD) test $(p=0.05)$. All data are expressed as the mean of three replicates \pm standard error (SE).

\subsection{Leaf Net Photosynthesis (Pn)}

Leaf net photosynthesis (Pn) was determined in the morning (from 9:00 a.m. to 11:00 a.m.) on cloudless days on nine expanded current-season leaves from nine control trees and nine treated trees, randomly sampled from well-lit canopy portions of trees, at the beginning of June, July, and August, when the incoming photosynthetic photon flux density (PPFD) was about 1880, 2050, and $2040 \mu \mathrm{mol} \mathrm{m} \mathrm{m}^{-2} \mathrm{~s}^{-1}$, respectively. Pn was determined using a portable ADC LCA-3 gas exchange analyzer (Analytical Development Company Ltd., Hoddesdon, UK) and a Parkinson-type assimilation chamber. After the gas exchange measurements, the leaves were immediately transferred to the laboratory in a portable refrigerator to determine the area.

\subsection{Vegetative and Productive Activity, Characteristics of Fruit}

The vegetative activity was estimated at the end of summer by measuring the height (h) and the canopy's average radius ${ }^{\circledR}$ on the same trees used for Pn measurements. R was calculated as the average of the radius of the basal, middle, and apical parts of the canopy, both within the row and in the direction perpendicular to it. The volume of the canopy was calculated as follows:

$$
\mathrm{V}=\pi \times \mathrm{r}^{2} \times \mathrm{h}
$$

Every year, the weight of the pruning material is recorded for the trees mentioned above. At the beginning of October and at the end of the same month (harvest time), detachment force, pigmentation, and fresh/dry weight of about 50 olives per tree were determined. Detachment force was assessed using a "Carpo" hand dynamometer ("Effe.gi" dynamometer DT 05, Alfonsine, Ravenna, Italy). The "Jean pigmentation index", ranging from 0 to 5 with 0 value for green olives and five values for olives with deep purple pigmentation of the pulp, respectively, was visually assessed. At the same time, the fruit production on eighteen control trees and eighteen treated ones was measured.

\subsection{Extraction of Total Bacterial DNA from Soil and OMWW}

Total bacterial DNA was extracted from about $0.25 \mathrm{~g}$ of soil and OMWW following the protocol of the MoBioPowerSoil DNA Isolation kit (Qiagen, Valencia, CA, USA). The quality and concentration of the extracted DNA were determined spectrophotometrically at 260, 280, and $230 \mathrm{~nm}$ using a NanoDrop ${ }^{\circledR}$ 2000c spectrophotometer (Thermo Fisher Scientific, Inc., Waltham, MA, USA). Low quality was noted for the DNA samples despite a good concentration. Therefore, extracts were amplified to test their efficiency. DNA was amplified using DreamTaq Green DNA Polymerase (ThermoFisher Scientific, Waltham, MA, USA) with the primer set 515F-806R to amplify the V4 region of the $16 \mathrm{~S}$ ribosomal RNA gene, following the protocol described by [55]. PCR products were stained with ethidium bromide, separated through $1.8 \%(w / v)$ agarose gel electrophoresis, and imaged 
under UV light. The DNA extracted from OMWW and some soil samples did not amplify the V4 region. Therefore, the authors set up a purification method for the extracts to allow the $16 \mathrm{~S}$ library preparation. According to Bolano et al. [56], samples were purified with some modification as reported in Supplementary Materials and Methods 1. Following the PCR protocol previously described, all the purified samples were successfully amplified.

\subsection{S Library Preparation and Sequencing}

For each sample of DNA, the taxonomic characterization of bacterial communities was carried out through a 16S-based metagenomics approach. Preparation of the $16 \mathrm{~S}$ library and sequencing were made by IGA Technology Services S.r.L. (Udine, Italy). Bacterial 16S library preparation workflow included two PCR amplifications. Initial PCR amplification was performed on genomic DNA to amplify the variable V3-V4 region of the $16 \mathrm{~S}$ ribosomal RNA gene. Gene-specific primers with overhang adapters were used for compatibility with Illumina index and sequencing adapters. The primer sequences, without the adapters, were: 16S-341F $5^{\prime}$-CCTACGGGNGGCWGCAG-3' and 16S-805R $5^{\prime}$-GACTACHVGGGTATCTAATCC-3' [57]. The PCR products were purified and used as the target for a limited cycle amplification to add Illumina flow-cell binding domains and dual index adapters using NexteraXT Index Kit (FC-131-1001/FC-131-1002). The resulting libraries were purified, quantified, and normalized. Up to 96 libraries were pooled and sequenced from both ends on an Illumina MiSeq, and more than 100,000 reads of about $300 \mathrm{bp}$ were generated.

\subsection{Bioinformatics Analysis}

Bioinformatic analyses were conducted using the Qiime2 (version 2018.11) software package [58]. The initial quality control of the reads and the demultiplexing were performed by Sequentia Biotech (Barcelona, Spain). Sequence joining was performed using the plugin vsearchjoin-pairs, and base pair reads were truncated (or trimmed) during denoising to $390 \mathrm{bp}$, and no trimming occurred on the left end of reads. Sequences denoising and chimera checking were conducted using the plugins of deblur denoise-16S [59] which produced a set of amplicon sequence variants (ASVs). Classification of $16 \mathrm{~S}$ data used a trained classifier with the Greengenes 99\% alignment taxonomy based on Greengenes 13.8 database $[60,61]$.

\subsection{Statistical Analysis}

\subsubsection{Microbial Diversity and Composition}

All statistical analyses were conducted, on soil samples, into the R environment with the aid of relevant packages [62]. Before the analysis, data were quality filtered to remove ASVs with less than ten total sequences.

Values of observed ASVs richness, Shannon and Simpson diversity indices were calculated using the function estimate_richness() and plotted with the function plot_richness(), "phyloseq" $R$ package [63]. To estimate the effects of OMWW spreading time, an analysis of variance was carried out after assessing for normality and homogeneity of variances. Means were separated using the Tukey Honest significant differences (HSD), as implemented in the HSD.test() function of the "agricolae" [64] package in R.

With the R package "vegan" [65], a permutational multivariate analysis of variance (PERMANOVA) was performed using the adonis() function to determine the effect of the period of treatment with OMWW and sampling depth.

Before calculating $\beta$-diversity, the dataset was normalized by rarefaction, as suggested by [66], using the rarefy_even_depth() function present in R package "phyloseq" [63]. A rarefaction curve was compiled utilizing the function iNEXT(), "iNEXT" $\mathrm{R}$ package [67], to choose a rarefaction depth.

Principal coordinate analysis (PCoA) was used to investigate community $\beta$-diversity. A canonical analysis of principal coordinates (CAP) ([68] constrained ordination was also performed using the Bray-Curtis dissimilarity matrix to display differences in soil microbial 
communities structure over time. Those analyses were performed through the ordinate function in the "phyloseq" [63] R package.

The differential abundances of the taxa among soil samples were determined by the ANCOM (Analysis of Composition of Microbiomes) method [69] by using Qiime2.

\subsubsection{Groves Characterization}

To study the correlation pattern of all soil chemicals variables and characterize the differences among treated and untreated grooves, a principal components analysis (PCA) was performed by using the function PCA () of the package "FactoMineR" [70].

\subsubsection{Redundancy Analysis}

The relationships among bacterial phyla abundance, bacterial communities (samples), and soil chemical variables were analyzed using redundancy analysis (RDA) with abundances of the ten most abundant phyla as dependent variables and the measured chemical properties as explanatory variables.

Initially, the most relevant chemical soil variables were identified. To this purpose, the phyla abundance matrix was Hellinger-transformed and submitted to factorial regression by using a stepwise forward approach [71], based on the AIC value [72], as implemented in the function stepAIC () on the R-package "MASS" [73].

In the second step, RDA was carried out, as implemented in the R-function rda(), in the package "Vegan" [65]. The transformed phyla abundance matrix was constrained by multiple regression against the standardized chemical variables selected in the previous step. The results were displayed on a "distance biplot" [74] together with the scores for soil chemical variables, representing their correlations with canonical axes.

\section{Results}

\subsection{Effect of OMWs Spreading on Soil Chemical Properties}

The results of soil chemical characteristics of unamended control, 14 days after spreading, one year and two years from the end of the OMWW spreading are reported in Tables 2 and 3 for $0-20$ and 20-40 cm, respectively. Fourteen days after spreading, the $\mathrm{pH}$ showed significantly lower values than the control at both depths due to the acidic $\mathrm{pH}$ of OMWW added to the soil. No changes in soil $\mathrm{pH}$ were observed in all other sampling times. The addition of OMWW also caused a significant increase of soil EC at 14 days after spreading at both depths. Afterward, a gradual reduction of salinity was observed. Concerning the TOC content, all soils did not show significant differences with mean values of 2 and $0.71 \%$ at $0-20$ and $20-40 \mathrm{~cm}$, respectively, except for a decrease in 2 years treated soils in the upper soil layers. Even the soluble organic $\mathrm{C}$ in alkaline solution (TEC) did not show significant change after OMWW application in the short period, except for a slight increase after one year. The WEOC concentration increased significantly, especially at 14 days after spreading at both depths, and then decreased over time, reaching values similar to the unamended control after two years. The addition of OMWW resulted in a slight significant increase of total $\mathrm{N}$ only after one year. In contrast, the available $\mathrm{P}$ was higher than the unamended control even after two years of treatment at both depths. In the short term (14 days), the exchangeable K increased in the upper soil layers, showing values similar to the unamended control after one year. The CEC did not show any change in the soils amended with OMWW and the concentration of exchangeable $\mathrm{Ca}$ and $\mathrm{Mg}$. 
Table 2. Chemical analysis of unamended control and soils treated 14 days, 1 and 2 years before at $0-20 \mathrm{~cm}$.

\begin{tabular}{|c|c|c|c|c|}
\hline \multirow{2}{*}{ Parameters } & \multicolumn{4}{|c|}{ Time } \\
\hline & Unamended_20 & 14 Days_20 & 1 Year_20 & 2 Year_20 \\
\hline $\mathrm{pH}$ & $8.2 \pm 0.1$ & $7.5 \pm 0.1$ & $8.0 \pm 0.0$ & $8.1 \pm 0.0$ \\
\hline $\mathrm{EC}(\mu \mathrm{S} / \mathrm{cm})$ & $342 \pm 21$ & $2660 \pm 30$ & $630 \pm 125$ & $333 \pm 5$ \\
\hline TOC (\%) & $2.00 \pm 0.23$ & $2.22 \pm 0.02$ & $2.27 \pm 0.01$ & $1.35 \pm 0.06$ \\
\hline TEC $(\%)$ & $1.27 \pm 0.38$ & $2.04 \pm 0.13$ & $2.70 \pm 0.03$ & $1.27 \pm 0.03$ \\
\hline WEOC (mg/kg) & $316.8 \pm 0.2$ & $3574.0 \pm 6.0$ & $815.4 \pm 65.4$ & $455.5 \pm 4.9$ \\
\hline TKN $(\%)$ & $0.17 \pm 0.04$ & $0.18 \pm 0.00$ & $0.39 \pm 0.02$ & $0.29 \pm 0.04$ \\
\hline CEC (meq/100 g) & $16.1 \pm 0.5$ & $14.1 \pm 0.3$ & $17.1 \pm 0.1$ & $13.8 \pm 0.0$ \\
\hline Available P (mg/kg) & $10.5 \pm 0.7$ & $86.7 \pm 1.5$ & $44.7 \pm 12.7$ & $48.5 \pm 3.3$ \\
\hline Exchangeable K (mg/kg) & $725 \pm 38$ & $2389 \pm 109$ & $1090 \pm 169$ & $767 \pm 13$ \\
\hline Exchangeable $\mathrm{Mg}(\mathrm{mg} / \mathrm{kg})$ & $168 \pm 7$ & $162 \pm 20$ & $169 \pm 15$ & $180 \pm 6$ \\
\hline Exchangeable Ca (mg/kg) & $8698 \pm 990$ & $7526 \pm 586$ & $6296 \pm 280$ & $10394 \pm 954$ \\
\hline
\end{tabular}

Table 3. Chemical analysis of unamended control and soils treated 14 days, 1 and 2 years before at $20-40 \mathrm{~cm}$.

\begin{tabular}{|c|c|c|c|c|}
\hline \multirow{2}{*}{ Parameters } & \multicolumn{4}{|c|}{ Time } \\
\hline & Unamended_40 & 14 Days_40 & 1 Year_40 & 2 Year_40 \\
\hline $\mathrm{pH}$ & $8.4 \pm 0.0$ & $7.9 \pm 0.0$ & $8.2 \pm 0.0$ & $8.4 \pm 0.0$ \\
\hline $\mathrm{EC}(\mu \mathrm{S} / \mathrm{cm})$ & $352 \pm 4$ & $1171 \pm 47$ & $516 \pm 50$ & $257 \pm 10$ \\
\hline TOC (\%) & $0.66 \pm 0.04$ & $1.02 \pm 0.01$ & $0.58 \pm 0.21$ & $0.60 \pm 0.09$ \\
\hline TEC $(\%)$ & $0.63 \pm 0.01$ & $0.98 \pm 0.03$ & $1.30 \pm 0.17$ & $0.67 \pm 0.03$ \\
\hline WEOC (mg/kg) & $284.3 \pm 15.5$ & $1134 \pm 9.2$ & $408.7 \pm 32.5$ & $414.0 \pm 14.4$ \\
\hline TKN $(\%)$ & $0.19 \pm 0.08$ & $0.15 \pm 0.01$ & $0.13 \pm 0.02$ & $0.19 \pm 0.01$ \\
\hline CEC (meq/100 g) & $13.7 \pm 0.7$ & $11.9 \pm 0.1$ & $11.5 \pm 2.0$ & $12.6 \pm 0.3$ \\
\hline Available P (mg/kg) & $6.3 \pm 0.8$ & $65.7 \pm 2.4$ & $26.1 \pm 8.4$ & $46.4 \pm 0.9$ \\
\hline Exchangeable K (mg/kg) & $603 \pm 8$ & $987 \pm 80$ & $715 \pm 232$ & $717 \pm 8$ \\
\hline Exchangeable $\mathrm{Mg}$ (mg/kg) & $169 \pm 16$ & $183 \pm 32$ & $121 \pm 20$ & $144 \pm 16$ \\
\hline Exchangeable Ca (mg/kg) & $9852 \pm 80$ & $8688 \pm 96$ & $5296 \pm 60$ & $8566 \pm 1014$ \\
\hline
\end{tabular}

\subsection{Leaf Net Photosynthesis (Pn)}

Soil amendment with OMWW did not significantly influence Pn. The highest photosynthesis values were recorded in June $\left(15.16 \pm 0.38\right.$ and $12.24 \pm 0.95 \mathrm{mmol} \mathrm{CO}_{2} \mathrm{~m}^{-2} \mathrm{~s}^{-1}$ for the control and treated trees, respectively) and July (10.71 \pm 2.29 and $13.45 \pm 0.62 \mathrm{mmol} \mathrm{CO}_{2} \mathrm{~m}^{-2} \mathrm{~s}^{-1}$ for the control and treated trees, respectively), without significant variations between control and treated trees. The lowest Pn values were recorded in August (9.02 \pm 1.09 and $6.87 \pm 0.81 \mathrm{mmol} \mathrm{CO}_{2} \mathrm{~m}^{-2} \mathrm{~s}^{-1}$ for the control and treated trees, respectively) in correspondence with a period characterized by the water deficiency and the high temperatures.

\subsection{Vegetative and Productive Activity, Characteristics of Fruit}

The canopy volume was not significantly different between control and treated trees $\left(14.55 \pm 0.32\right.$ and $14.73 \pm 0.78 \mathrm{~m}^{3}$ for the control and treated trees, respectively). The pruning weight recorded did not show statistical differences between control and treated trees $(18.85 \pm 1.4$ and $17.74 \pm 2.5 \mathrm{~kg}$ for the control and treated trees, respectively). The amendment with OMWW did not influence the production per tree and the fruits' fresh and dry weight, color, and oil content.

\subsection{High-Throughput Sequencing Results}

After quality filtering, the total reads were 289,299 in soil and 75,831 in OMWW, with a total of 5190 and 80 ASVs, respectively. An average number of approximately 12,000 and 19,000 reads/samples were reported. OMWW samples were investigated only in their bacterial composition, and no further analysis was carried out.

\subsection{Bacterial Composition of Soil and OMWW}

Relative abundances at the phylum level (Relative abundance $>1 \%$ ) for each analyzed soil sample were calculated and reported in Figure 1. The bacterial communities in the 
olive grove soil were dominated overall by Proteobacteria (23.6\%), Firmicutes $(22.1 \%)$, and Actinobacteria (20.6\%). Considering the soil treatment period, it was possible to determine that Firmicutes (33.9\%) dominate the soil not treated with OMWW, whereas Proteobacteria was the most represented phylum in 14-days (37.9\%) and 1-year (26.79\%) samples. The soil where OMWW spreading stopped two years before presented a high presence of Actinobacteria (25.82\%).

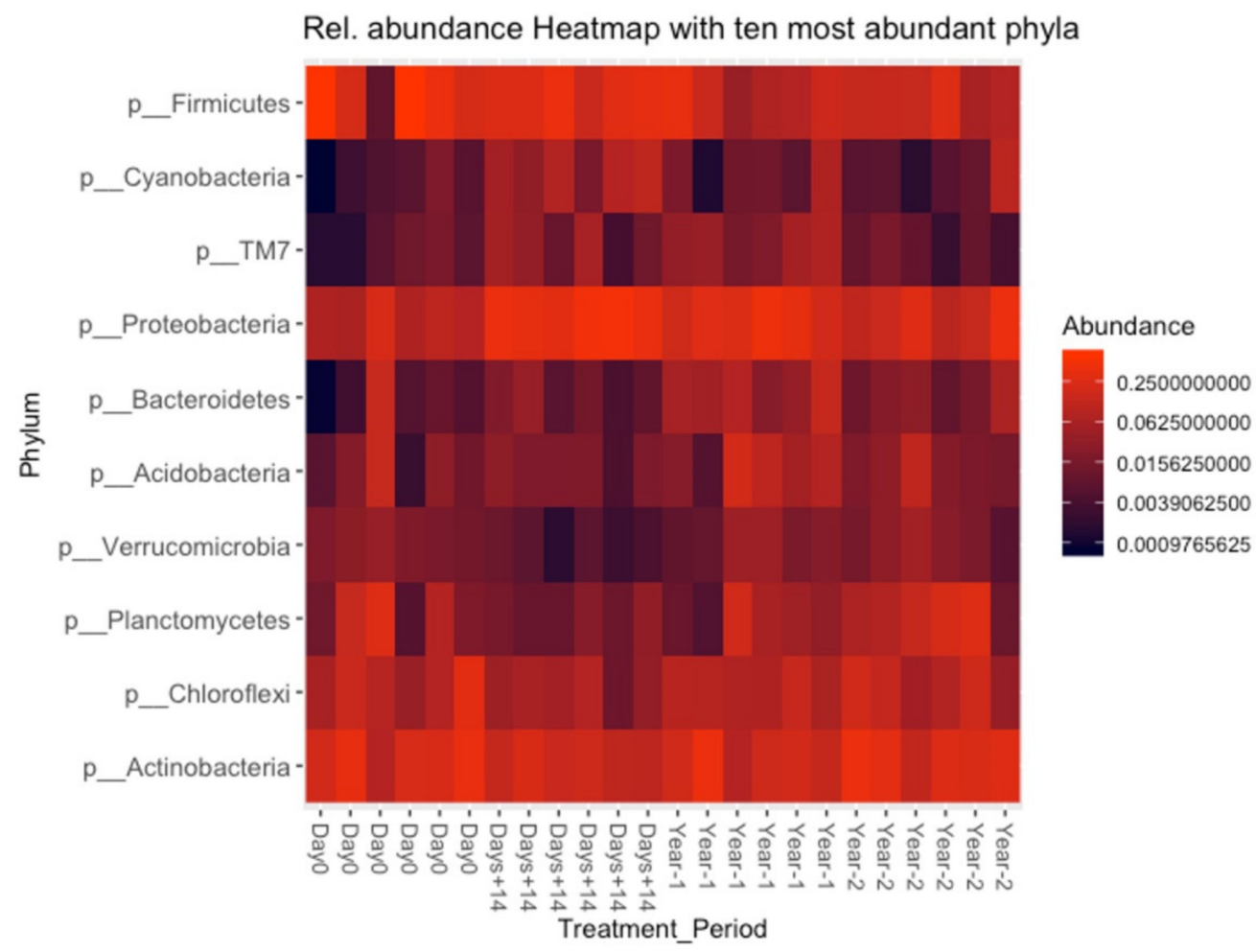

Figure 1. Relative abundance heatmap based on ten most abundant bacterial phyla and different periods of OMWW treatment.

Relative abundance (relative abundance $>1 \%$ ) was also calculated for OMWW. The bacterial communities were characterized only by Cyanobacteria (91.2\%) and Proteobacteria $(8.8 \%)$ in these samples. Whereas among Proteobacteria, the Gammaproteobacteria and Alphaproteobacteria classes were described, in Cyanobacteria, the only Chloroplast class was recognized. In OMWW, four ASVs represented 93.4\% of the total reads (Supplementary Table S1). Therefore, to find a more precise taxonomic identification, their sequences were used as queries against the GenBank [75] database using the Basic Local Alignment Search Tool (BLAST) algorithm [76]. Two of them were associated with the chloroplast genome; the other two showed a BLAST match $\geq 98 \%$ to Cronobacter sakazakii and mitochondrion genome of Olea europaea, respectively.

\subsection{Microbial Richness}

Supplementary Table S2 shows the observed richness, Shannon's diversity index, and Simpson's dominance index for the four treatment periods. Despite Shannon and Simpson indexes reported a lower diversity in 14-days samples, no significant differences $(p>0.05)$ in ASVs richness of the bacterial community were found between the periods of treatment (data not shown).

\subsection{Comparison of Soil Bacterial Communities over Time ( $\beta$-Diversity)}

PERMANOVA analysis applied to the Bray-Curtis dissimilarity distance matrix confirmed a significant effect of the treatment with OMWW on the bacterial communities 
$(p \leq 0.05)$. On the other hand, the same analysis showed no significant impact of the sampling depth on the prokaryotic communities $(p>0.05)$.

Principal coordinate analysis (PCoA) ordination graph (Supplementary Figure S1), performed on the $16 \mathrm{~S}$ rDNA data, shows that the difference between prokaryotic communities of the no-treated soil and the 2-Years samples with the more recently treated samples (14-days and 1-year) explained the variance obtained in the first axis (19\%). On the other hand, the second axis (11.3\%) does not show a persistent pattern according to treatment time.

The CAP ordination explains approximately $25 \%(17.7 \%$ in the first and $7.6 \%$ in the second dimension, respectively) of the total variance observed in bacterial communities (Figure 2). This ordination graph separated data into three groups, 2-Years+no-treatment, 1-year, and 14-days. This evidence showed a similar structure of bacterial communities in 2-years and no-treated samples.

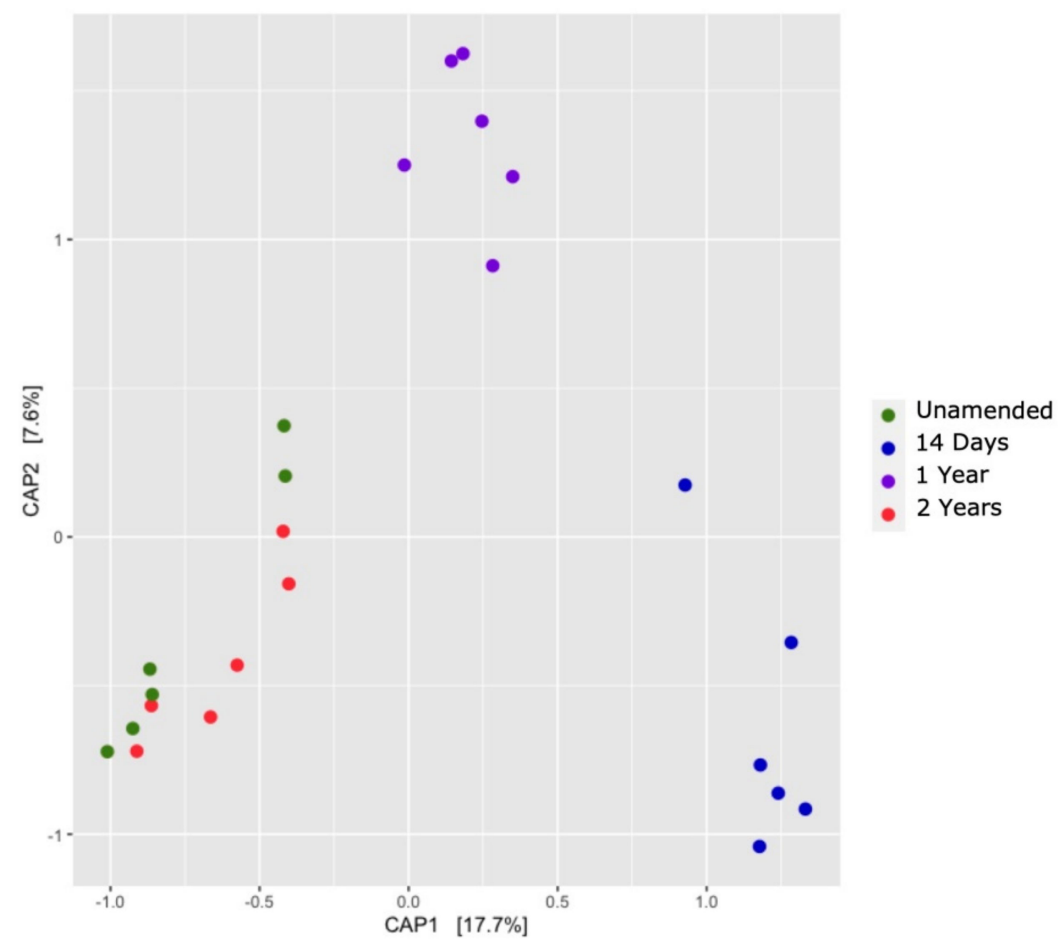

Figure 2. Constrained analysis of principal coordinates (CAP) of the bacterial communities characterized in different periods of OMWW treatment.

\subsection{Differential Abundance Analysis (ANCOM)}

We used ANCOM differential abundance analysis using QIIME2 to visualize the bacterial taxa that significantly differed among the soil samples by treatment period. Overall, ANCOM statistical results reported that 12 ASVs significantly differed (null hypothesis rejected) among samples, according to the treatment period (Table 4). Table 5 shows also the ANCOM percentile abundance of features by the treatment period for the significantly differing ASVs. All the significantly different ASVs were associated with the 14-days sample category; in particular, two of them (c98061c433607fe4b2f06fceb61c7458 and 67465099c7e7995ae38f287944b6094f) were clear outliers in the ANCOM volcano plot (Supplementary Figure S2), with high values for both W (the number of null hypotheses rejected) and clr (effect size). These two had high sequence similarity using NCBI blastn to Kosakonia arachidis and Mangrovi bacterplantisponsor species, both belonging to the Enterobacteriaceae family. 
Table 4. ANCOM analysis: different relative abundance in overall ASVs.

\begin{tabular}{|c|c|c|c|}
\hline ANCOM Results (ASVs) & Reject Null Hypothesis & W & Taxonomy \\
\hline 54006fd3be9a8609d4a2d04f12573a0c & True & 7524 & k_Bacteria;p_Proteobacteria;c_Gammaproteobacteria;o_Enterobacteriales;f_Enterobacteriaceae; \\
\hline 040ff57af2e17018f490b96f4451a3e4 & True & 7458 & k_Bacteria;p_Proteobacteria;c_Gammaproteobacteria;o_Enterobacteriales;f_Enterobacteriaceae; \\
\hline 1ae7ead5138fa5145ad71abc1bb2e776 & True & 7424 & k_Bacteria;p_Firmicutes;c_Bacilli;o_Bacillales;f_Sporolactobacillaceae;g_Sporolactobacillus; \\
\hline 1157032931d4b8ce4a851e95cfcc3c33 & True & 7232 & k_Bacteria;p_Firmicutes;c_Clostridia;o_Clostridiales;f_Clostridiaceae;g_Clostridium;s_butyricum \\
\hline 8afe5e8dbfe1fbab3b787103dba1ce81 & True & 7514 & k_Bacteria;p_Proteobacteria;c_Alphaproteobacteria;o_Sphingomonadales;f_Sphingomonadaceae;g_Novosphingobium \\
\hline 1653005b37d2ba3490c18db3359794ff & True & 7116 & k_Bacteria;p_Firmicutes;c_Clostridia;o_Clostridiales;f_Lachnospiraceae;g_Coprococcus \\
\hline 7da1250b471f87c40c9fc162c3ead212 & True & 7256 & k_Bacteria;p_Firmicutes;c_Clostridia;o_Clostridiales;f_Clostridiaceae;g_Clostridium;s_butyricum \\
\hline 67465099c7e7995ae38f287944b6094f & True & 7399 & k_Bacteria;p_Proteobacteria;c_Gammaproteobacteria;o_Enterobacteriales;f_Enterobacteriaceae;g_Trabulsiella \\
\hline b95025e3d0cb9ce8c4807ce2737bdf1a & True & 7499 & k_Bacteria;p_Firmicutes;c_Bacilli;o_Bacillales;f_Sporolactobacillaceae;g_Sporolactobacillus \\
\hline c98061c433607fe4b2f06fceb61c7458 & True & 7442 & k_Bacteria;p_Proteobacteria;c_Gammaproteobacteria;o_Enterobacteriales;f_Enterobacteriaceae;g_Enterobacter \\
\hline e4a1ebdc1ea26629eca90e0fb4c34245 & True & 7266 & p_Proteobacteria;c_Gammaproteobacteria;o_Enterobacteriales;f_Enterobacteriaceae \\
\hline 311a58a1ae5008a2ccde8f7a41710be7 & True & 7160 & k_Bacteria;P_Proteobacteria;c_Alphaproteobacteria;o_Rhodospirillales;f_Acetobacteraceae;g_Gluconobacter \\
\hline
\end{tabular}

Table 5. ANCOM analysis: details of ASVs and period of OMWW treatment.

\begin{tabular}{|c|c|c|c|c|c|c|c|c|c|c|c|c|c|c|c|c|c|c|c|c|}
\hline Percentile & 0 & 25 & 50 & 75 & 100 & 0 & 25 & 50 & 75 & 100 & 0 & 25 & 50 & 75 & 100 & 0 & 25 & 50 & 75 & 100 \\
\hline Group & Unam. & Unam. & Unam. & Unam. & Unam. & 14D & 14D & 14D & 14D & 14D & $1 Y$ & $1 Y$ & $1 Y$ & $1 Y$ & $1 Y$ & $2 Y$ & $2 \mathrm{Y}$ & $2 \mathrm{Y}$ & $2 \mathrm{Y}$ & $2 Y$ \\
\hline 54006fd3be9a8609d4a2d04f12573a0c & 1 & 1 & 1 & 1 & 1 & 160 & 495.5 & 725 & 901.25 & 1867 & 1 & 1 & 1 & 1 & 52 & 1 & 1 & 1 & 1 & 1 \\
\hline 040ff57af2e17018f490b96f4451a3e4 & 1 & 1 & 1 & 1 & 1 & 8 & 113.75 & 165.5 & 176.75 & 539 & 1 & 1 & 1 & 1 & 1 & 1 & 1 & 1 & 1 & 1 \\
\hline 1ae7ead5138fa5145ad71abc1bb2e776 & 1 & 1 & 1 & 1 & 1 & 48 & 80.25 & 179.5 & 216.5 & 296 & 1 & 1 & 1 & 8.5 & 14 & 1 & 1 & 1 & 1 & 2 \\
\hline 1157032931d4b8ce4a851e95cfcc3c33 & 1 & 1 & 1 & 1 & 2 & 109 & 178.75 & 219.5 & 417 & 676 & 1 & 1 & 7 & 15.25 & 23 & 1 & 1 & 1 & 9.25 & 25 \\
\hline 8afe5e8dbfe1fbab3b787103dba1ce81 & 1 & 1 & 1 & 1 & 1 & 166 & 397.5 & 583.5 & 899.25 & 1014 & 1 & 1 & 1 & 1 & 64 & 1 & 1 & 1 & 1 & 3 \\
\hline 7da1250b471f87c40c9fc162c3ead212 & 1 & 1 & 1 & 1 & 9 & 113 & 129.75 & 162 & 258 & 342 & 1 & 2.25 & 6.5 & 15.25 & 19 & 1 & 1 & 1.5 & 2 & 13 \\
\hline 67465099c7e7995ae38f287944b6094f & 1 & 1 & 1 & 1 & 1 & 19 & 33.5 & 67 & 90 & 151 & 1 & 1 & 1 & 1 & 1 & 1 & 1 & 1 & 1 & 1 \\
\hline b95025e3d0cb9ce8c4807ce2737bdf1a & 1 & 1 & 1 & 1 & 1 & 194 & 353.75 & 550.5 & 975.25 & 1523 & 1 & 1 & 5 & 24.75 & 39 & 1 & 1 & 1 & 1 & 20 \\
\hline c98061c433607fe4b2f06fceb61c7458 & 1 & 1 & 1 & 1 & 1 & 24 & 42.75 & 92 & 108.25 & 226 & 1 & 1 & 1 & 1 & 1 & 1 & 1 & 1 & 1 & 1 \\
\hline e4a1ebdc1ea26629eca90e0fb4c34245 & 1 & 1 & 1 & 1 & 1 & 13 & 26.25 & 45.5 & 76 & 158 & 1 & 1 & 1 & 1 & 3 & 1 & 1 & 1 & 1 & 1 \\
\hline 311a58a1ae5008a2ccde8f7a41710be7 & 1 & 1 & 1 & 1 & 1 & 1 & 433.75 & 649.5 & 900.5 & 1378 & 1 & 1 & 1 & 1 & 1 & 1 & 1 & 1 & 1 & 1 \\
\hline
\end{tabular}


To better elucidate the dynamics and changes in bacterial communities over time, we carried out ANCOM analysis on pairs of treatment period categories. Table 6 shows as significant differences in ASVs abundance was detectable comparing no-treated soil vs. 14-days (6 ASVs), 14-days vs.1-year (2 ASVs), and 14-days vs. 2-years (5 ASVs). ANCOMreturned ASVs were all associated with the 14-days samples (data not shown). We did not find any ASV that significantly differed comparing no-treated soil vs. 1-year and 2-years and 1-year vs. 2-years.

\subsection{Groves Characterization}

The first two PCA axes accounted for $74.77 \%$ of total data variability, and the biplot highlighted some notable differences among groves and depths (Figure 3). In detail, the PCA showed two clusters: samples named Unamended_40, two years_40, and one year_40 belonged to the first one, while samples named 14 days_40, Unamended_20, and two years_20 belonged to the second one. In particular, these Unamended_20 and two years_20 appeared very similar. Samples 14 days_20 and one year_20 were discriminated with respect to other groves on the PC1. In contrast, they discriminated each other to a slightly lower extent on this same PC1 and discriminated each other on PC2.

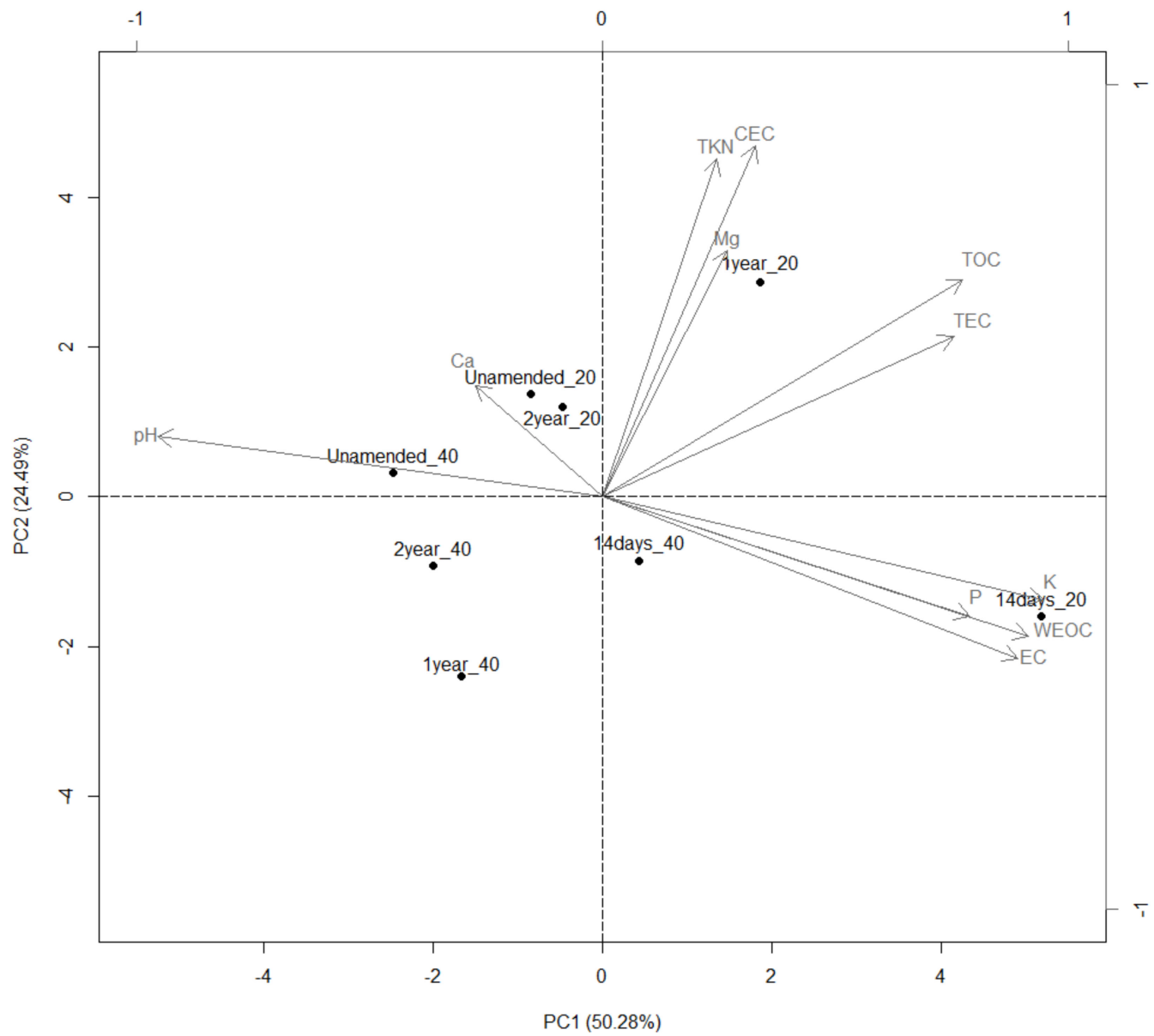

Figure 3. Principal component analysis (PCA) of soil grooves based on the 11 recorded chemical variables. Black dots represent the soil grooves, while grey arrows represent the chemical variables. 
Table 6. Pairwise ANCOM analysis of ASVs abundance comparing unamended soil vs. 14-Days (6 ASVs), 14-Days vs.1-Year (2 ASVs) and 14-Days vs. 2-Years (5 ASVs).

\begin{tabular}{|c|c|c|c|c|}
\hline Pairwise Comparison & Group & $\begin{array}{l}\text { Reject Null } \\
\text { Hypothesis }\end{array}$ & $\mathbf{W}$ & Taxonomy \\
\hline Unamended vs. 14 days & 1157032931d4b8ce4a851e95cfcc3c33 & True & 5770 & k_Bacteria;p_Firmicutes;c_Clostridia;o_Clostridiales;f_Clostridiaceae;g_Clostridium;s_butyricum \\
\hline Unamended vs. 14 days & 7da1250b471f87c40c9fc162c3ead212 & True & 5346 & k_Bacteria;p_Firmicutes;c_Clostridia;o_Clostridiales;f_Clostridiaceae;g_Clostridium;s_butyricum \\
\hline Unamended vs. 14 days & b95025e3d0cb9ce8c4807ce2737bdf1a & True & 5844 & k_Bacteria;p_Firmicutes;c_Bacilli;o_Bacillales;f_Sporolactobacillaceae;g_Sporolactobacillus \\
\hline Unamended vs. 14 days & 54006fd3be9a8609d4a2d04f12573a0c & True & 5852 & k_Bacteria;p_Proteobacteria;c_Gammaproteobacteria;o_Enterobacteriales;f_Enterobacteriaceae \\
\hline Unamended vs. 14 days & 8afe5e8dbfe1fbab3b787103dba1ce81 & True & 5847 & k_Bacteria;p_Proteobacteria;c_Alphaproteobacteria;o_Sphingomonadales;f_Sphingomonadaceae;g_Novosphingobium \\
\hline Unamended vs. 14 days & 1ae7ead5138fa5145ad71abc1bb2e776 & True & 5466 & k_Bacteria;p_Firmicutes;c_Bacilli;o_Bacillales;f_Sporolactobacillaceae;g_Sporolactobacillus; \\
\hline 14 days vs. 1 year & 67465099c7e7995ae38f287944b6094f & True & 3729 & k_Bacteria;p_Proteobacteria;c_Gammaproteobacteria;o_Enterobacteriales;f_Enterobacteriaceae;g_Trabulsiella \\
\hline 14 days vs. 1 year & c98061c433607fe4b2f06fceb61c7458 & True & 3931 & k_Bacteria;P_Proteobacteria;c_Gammaproteobacteria;o_Enterobacteriales;f_Enterobacteriaceae;g_Enterobacter \\
\hline 14 days vs. 2 years & b95025e3d0cb9ce8c4807ce2737bdf1a & True & 5497 & k_Bacteria;p_Firmicutes;c_Bacilli;o_Bacillales;f_Sporolactobacillaceae;g_Sporolactobacillus;s_ \\
\hline 14 days vs. 2 years & 54006fd3be9a8609d4a2d04f12573a0c & True & 5922 & k_Bacteria;p_Proteobacteria;c_Gammaproteobacteria;o_Enterobacteriales;f_Enterobacteriaceae;; \\
\hline 14 days vs. 2 years & 8afe5e8dbfe1fbab3b787103dba1ce81 & True & 5910 & k_Bacteria;p_Proteobacteria;c_Alphaproteobacteria;o_Sphingomonadales;f_Sphingomonadaceae;g_Novosphingobium;s_ \\
\hline 14 days vs. 2 years & e3d383866de994753086e21bf41b6947 & True & 5368 & k_Bacteria;p_Cyanobacteria;c_Chloroplast;o_Chlorophyta;f_;g_;s_ \\
\hline 14 days vs. 2 years & 1ae7ead5138fa5145ad71abc1bb2e776 & True & 5409 & k_Bacteria;p_Firmicutes;c_Bacilli;o_Bacillales;f_Sporolactobacillaceae;g_Sporolactobacillus;s_ \\
\hline
\end{tabular}


Chemical soil variables seem to differentiate the samples collected at different depths very well. All the chemical soil variables had significant effects on the ordination of groves (as indicated by the lengths of their vectors). The variables were clustered into three groups: the first one included TKN, CEC, exchangeable Mg, TOC, and TEC, the second one had exchangeable $\mathrm{K}$, available $\mathrm{P}, \mathrm{WEOC}$, and $\mathrm{EC}$, while the third group included $\mathrm{Ca}$ and $\mathrm{pH}$. Within each group, variables were highly positively correlated. Still, the variables belonging to the first group were generally negatively correlated to $\mathrm{pH}$, and they did not correlate with those belonging to the other remaining group and $\mathrm{Ca}$. The variables belonging to the second group were negatively correlated to both $\mathrm{pH}$ and $\mathrm{Ca}$. Both Unamended samples, one year_40, two years_20, and 40 samples, were mainly characterized by high (aboveaverage) values of $\mathrm{pH}$ and Ca. Samples 1 year_20 were characterized primarily by high (above-average) CEC, TKN, Mg, TEC, and TOC values. In contrast, sample 14 days_20 was mainly characterized by high (above-average) values of other chemicals in the soil. Finally, sample 14 days_40 was characterized by high values, on average, of all chemical soil variables.

\subsection{Redundancy Analysis}

The chemical variables selected by the "forward" stepwise factorial regression procedure were: EC, TEC, exchangeable $\mathrm{Ca}$, available $\mathrm{P}$, and exchangeable $\mathrm{Mg}$. These variables explained $49.56 \%$ of the variability in the species abundance matrix.

The biplot derived from RDA for species abundance shows a clear representation of the relationships between chemical soil variables, bacterial communities scores, and Phyla scores (Figure 4 ). The first axis accounted for $22.11 \%$ of the variation, while the second axis accounted for $17.28 \%$ (for $39.39 \%$ of total abundance variation). All fitted variables were located at about the same distance from the center of the biplot (Figure 4), indicating that they had the same effect on the abundance matrix, except $\mathrm{Mg}$, which had the lowest impact. TEC, available $\mathrm{P}$, and EC were positively correlated; in particular, EC and P had opposite effects with respect to $\mathrm{Ca}$ and $\mathrm{Mg}$ along Axis 1; while TEC had opposite effects with respect to $\mathrm{Ca}$ and $\mathrm{Mg}$ along Axis 2 (Figure 4). At the same time, $\mathrm{Mg}$ and $\mathrm{Ca}$ were highly positively correlated.

The bacterial communities named one year_40, 14 days_20, and 14 days_40 were characterized by phyla mainly positively influenced by high (above-average) values of EC, available $\mathrm{P}$, and TEC, and low values of $\mathrm{Ca}$ and $\mathrm{Mg}$. In contrast, the bacterial communities named two years_20, two years_40 and which found unamended control were constituted by phyla which were positively influenced by high (above-average) values of $\mathrm{Ca}$ and $\mathrm{Mg}$ and consequently by low (below-average) values of EC, P, and TEC. The bacterial communities named one year_20 were characterized by phyla mainly positively influenced by high (above-average) TEC and available $p$ values; they were not affected by EC and were negatively impacted by high (above-average) values of exchangeable $\mathrm{Mg}$ and exchangeable Ca. Only the replicates two year_20a, two year_40a, and Unamended_20c showed opposite behavior with respect to the other replicates of the same samples.

Regarding phyla, Firmicutes (second quadrant) and Proteobacteria (third quadrant), which were the most abundant phyla, were very distant from each other in terms of their score on Axis 2 and from all the other phyla along Axis 1. Other major bacterial phyla, such as Actinobacteria, Chloroflexi, and Gemmatimonadetes, were spread in Quadrant I, while Acidobacteria, Bacteroidetes, Planctomycetes, and Verrucomicrobia were spread in Quadrant IV. In addition, these phyla could be considered indicators of high or low values of the variables fitted in this model. Proteobacteria were favored by high (above-average) EC, available $\mathrm{P}$, and TEC values and low (below-average) values of $\mathrm{Ca}$ and $\mathrm{Mg}$. Firmicutes were selected by high (above-average) EC, $\mathrm{Ca}$, and $\mathrm{Mg}$ values, and it was not influenced by $\mathrm{P}$, while it negatively affected TEC. Acidobacteria and Bacteroidetes were favored by high (above-average) values of TEC and available $P$ and by low (above-average) values of $\mathrm{Ca}$ and $\mathrm{Mg}$, while EC did not influence them. Finally, the other most abundant phyla: Actinobacteria, Chloroflexi, Verrucomicrobia, Planctomycetes, and Gemmatimonadetes, 
took advantage of high (above-average) values of $\mathrm{Ca}$ and $\mathrm{Mg}$, while they were negatively correlated to EC, available $\mathrm{P}$, and TEC.

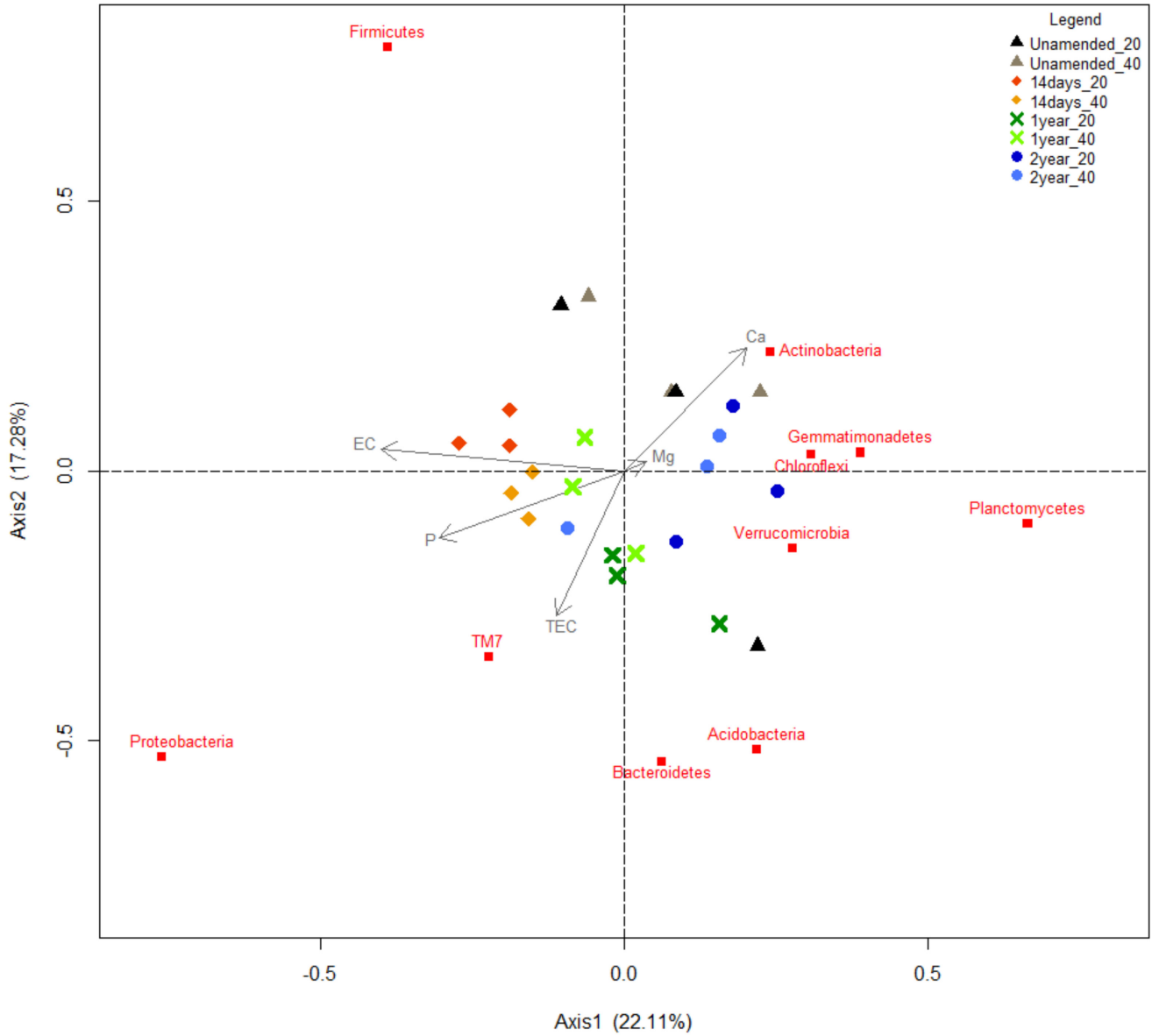

Figure 4. Reduced rank factorial regression biplot based on ten most abundant bacterial phyla, 24 soil samples, and the fitted chemical variables. Arrows refer to the coefficients for chemical variables within the reduced rank factorial regression axes. Red squares represent the bacterial phyla, while dots, diamonds, crosses, and triangles represent the soil sample.

Regarding phyla, Firmicutes (second quadrant) and Proteobacteria (third quadrant), which were the most abundant phyla, were very distant from each other in terms of their score on Axis 2 and from all the other phyla along Axis 1. Other major bacterial phyla, such as Actinobacteria, Chloroflexi, and Gemmatimonadetes, were spread in Quadrant I, while Acidobacteria, Bacteroidetes, Planctomycetes, and Verrucomicrobia were spread in Quadrant IV. In addition, these phyla could be considered indicators of high or low values of the variables fitted in this model. Proteobacteria were favored by high (above-average) EC, available $\mathrm{P}$, and TEC values and low (below-average) values of $\mathrm{Ca}$ and $\mathrm{Mg}$. Firmicutes were selected by high (above-average) $\mathrm{EC}, \mathrm{Ca}$, and $\mathrm{Mg}$ values, and it was not influenced by $\mathrm{P}$, while it negatively affected TEC. Acidobacteria and Bacteroidetes were favored by high (above-average) values of TEC and available P and by low (above-average) values of $\mathrm{Ca}$ and $\mathrm{Mg}$, while EC did not influence them. Finally, the other most abundant phyla: Actinobacteria, Chloroflexi, Verrucomicrobia, Planctomycetes, and Gemmatimonadetes, took advantage of high (above-average) values of $\mathrm{Ca}$ and $\mathrm{Mg}$, while they were negatively correlated to EC, available $\mathrm{P}$, and TEC.

\section{Discussion}

\subsection{Soil Chemical Changes after OMWW Application}

Farmers have indicated repeated application of OMWW on fields as a valuable and free practice for recycling olive waste products. However, data on their effects on mi- 
croorganisms that inhabit the soil are still lacking. It has been previously demonstrated that the application of OMWW improves soil fertility in terms of organic matter and macronutrients $[13,77,78]$. Nevertheless, the OMWW is also characterized by acidic $\mathrm{pH}$ and high salinity [8], which might negatively affect soil properties in the short term. A sharp decrease of soil $\mathrm{pH}$ after OMWW was observed in previous studies, and it is mainly due to the presence of organic acids $[17,24]$. Here, the soil pH decreased within two weeks, with the risk of causing a greater solubility and mobility of heavy metals or forming insoluble compounds with phosphates. Afterward, the capacity of the soil to restore the $\mathrm{pH}$ conditions was observed, likely attributable to the soil carbonate alkalinity able to neutralize the acidic $\mathrm{pH}$ of OMWW [13,77]. Moreover, the high salt concentration of the OMWS increased the soil EC in the short term, reaching values below the salinity threshold, as also observed by Di Bene et al. [24]. In addition, the use of fresh organic material with a high content of soluble organic C, i.e., WEOC, affected the short-term variations of soluble organic matter of soil [2,20]. The WEOC added with the OMWW probably increased the microbial activity, hence respiration, even leading to changes in soil microbial community structure, as demonstrated by the microbiological analysis. In a similar study, Federici et al. [2] observed not only the consumption of WEOC but also the decrease of soluble compounds, as total reducing sugars and total phenolic compounds within 60 days. The soil total $C$ did not change, except for a slight reduction in 2 years soils at $0-20 \mathrm{~cm}$, suggesting that the addition of OMWW promoted the organic matter mineralization by microorganisms [17]. This behavior might be confirmed by the small increase of TEC only in 1 year treated soils, suggesting that the OMWW did not induce overall the formation of humic-like substances in the long term. Conversely, a positive effect of OMWW application was observed for organic and mineral matter's contents of poorly organic matter soil, even if the impacts depend by the dose added, as well as by the application of OMWW for long periods (5 and 15 years) [13,78,79]. The improvement of macronutrients with the addition of OMWW is well known [8], and in this study it concerns mainly the increase of available $\mathrm{P}$ in long term, which is probably attributable to its organic form added to the OMWW. Di Bene et al. [24] found similar results, observing a significant impact of OMWW spreading for available $\mathrm{P}$ content, even if this parameter led to a decrease after 6 months.

\subsection{Microbial Community Changes after OMWW Application}

Many authors investigated changes in microbial communities related to soil properties and abiotic factors [80-82], but very little information is available on the correlation between soil microbial communities and soil chemical characteristic after the OMWW treatment. The results of our analysis show that the most abundant bacterial phyla are Firmicutes, Actinobacteria, Proteobacteria, and Chloroflexi. Similar results were found by Pezzolla et al. [83], who observed that three Gram-negative (Acidobacteria, Proteobacteria, and Bacteroidetes) and one Gram-positive (Actinobacteria) phyla accounted for over $85 \%$ of the total abundance in a study where the digestate was used as amendement.

Long-term inorganic or organic amendment at a low rate may affect microbial community structure and biomass $[84,85]$. These works demonstrated that the long-term effects of different fertilization treatments affected the most abundant phyla as Actinobacteria, followed by Proteobacteria, Acidobacteria, Chloroflexi, and Firmicutes. As suggested by different authors, these phyla are the most abundant during the composting processes using different organic wastes [86-88]. In particular, regarding olive mill waste, Tsiamis et al. [38] reported that the structure of microbial communities was influenced by specific cultivar from which the olive mill waste was generated. However, our results regarding the composition and abundance of soil microbial communities, reflect what was found by other authors who investigated the bacterial structure of olive-processing wastes and soils treated with OMWW [36,37,89-93]. In these studies, members of Firmicutes and Proteobacteria followed by Actinobacteria and Bacteroidetes, Acidobacteria, Chloroflexi, Synergistetes and the candidate division TM7 were found in soils treated with olive wastes and untreated soil. 
In our study, Firmicutes and Proteobacteria were the two most represented phyla, even if a different trend was observed after 14 days from the OMWW spreading. In fact, the phylum of Firmicutes seems to be negatively affected by the addition of OMWW, probably due to high presence of soluble C, as shown by the RDA analysis. Several authors suggested that the phylum Firmicutes, as well as the Gram-positive bacteria, are negatively influenced by a high level of phenolics compounds present in OMWW [5,44]. Chu et al. [81] suggested that also soil $\mathrm{pH}$ affected the relative abundances of the phyla, and this is also possibly observed at the sub-phylum level. In this case the decrease of $\mathrm{pH}$ probably was disadvantageous for the bacteria, and favored fungal growth [94]. On the contrary, Proteobacteria (Gram-negative) increased in the soil samples collected at 14 days after OMWW spreading, indicating that this phylum was positively affected by the addition of OMWW, and hence by $\mathrm{C}$ availability, confirming its role of fast-growing microorganisms, namely r-strategists $[83,85,95,96]$.

Among Proteobacteria, Enterobacteriaceae family was found to be the most abundant 14 days after the OMWW spreading. The same family was previously described by Ammar et al. [10] that found that Enterobacteria Citrobacter is actively involved in the aromatic acid degradation during the first stage of natural OMWW treatment. Bacteria belonging to this family may have a growth effect on plant of genus Olea [97]. Moreover, species belonging to Enterobacteriaceae promote growth, yield, and nutrient uptake on wheat, while they have promoting growth effects on Vigna radiata L. plants under salt stress conditions $[98,99]$. All these clues led the authors to hypothesize that further studies should be addressed in the future to better elucidate the biological mechanisms involved in Enterobacteriaceae and Olea europaea L. with the aim to describe potential effects of this bacterial taxa on olive trees.

In addition, Mechri et al. [3] suggested that Gram-negative bacteria are stress-tolerant, grow more rapidly than Gram-positive bacteria in OMWW amended soil, and tend to better metabolize complex $C$ substrates readily than Gram-positive bacteria. Our results confirmed this property of Gram-negative bacteria. In fact, as shown in RDA, Protobacteria, Bacteroides, and Acidobacteria take advantage from $\mathrm{C}$ availability. Finally, other evidence about the capacity of Gram-negative bacteria on utilization of $C$ was found by Pezzolla et al. [83], which observed that the growth of some copiotrophic bacteria belonging to Proteobacteria and Bacteroidetes was stimulated by the addition of the digestate. It has been previously observed that fast-growing Gram-negative bacteria proliferate after the addition of organic materials $[100,101]$. Gram-negative bacteria, such as Proteobacteria, found in the soil seem to be a more sensitive indicator of soil fertility than fungi and Actinomycetes [100].

Acidobacteria, even if it is a Gram-negative phylum, grows in abundance for a relatively long period after the treatment. Moreover, Siles et al. [102] observed an overall decrease in this phylum abundance in amended samples with OMWW, even which inputs affected the growth of Acidobacteria was not clear. In our results, this phylum seems to be negatively influenced by a high value of $\mathrm{EC}$, and to take advantage from high value of C. Although Acidobacteria include many oligotrophic members [103,104], some of them, such as Gp4 and Gp6, were abundant in soils with high contents of soil C [105,106].

Actinobacteria, belonging to the Gram-positive bacteria, as the Firmicutes, decreased after the OMWW treatment, but after 2 years their abundance returns similar to the unamended soil. Mekki et al. [43] and Mechri et al. [44] reported a positive effect of OMWW on these taxa over the short-term, but, on the other hand, [107] suggested that OMWW is responsible for dramatic alterations of Actinobacteria presence. [108] suggested that culturable Actinobacteria responded differently to amendment with untransformed and transformed dry olive depending on the phylogenetic group considered. Our results highlighted that Actinobacteria takes advantages from the high level of exchangeable $\mathrm{Ca}$, which was found in untreated soil or in soil sampled after 2 years from the treatments.

Finally, the changes in the abundance and diversity of microorganisms after the application of olive wastes in microbial communities are probably due to different causes $[107,109,110])$. 
For example, Mechri et al. [44] speculate that the impact of olive wastes on soil microbiology is a result of complex and sometimes conflicting effects related to the amounts of beneficial or inhibiting components for each microorganism applied with the treatment.

\subsection{Olive Tree Production after OMWW Application}

The OMWW application in our experiments did not negatively affect any of the olive tree parameters monitored, olive yield, fruit, and oil characteristics. After 10 and 14 months of OMWW application, Proietti et al. [111] also found no differences in photosynthesis rate among OMWW treated and control olive trees. Chartzoulakis et al. [112] applied OMWW to a Cretan orchard with 20-year-old trees (cv. Kalamata) during winter time for 3 consecutive years, at a maximum annual rate of $420 \mathrm{~m}^{3} \mathrm{ha}^{-1}$ and did not observe any negative effects on plant behavior. Regarding the olive production in a field test, [113] did not report any significant changes when $50 \mathrm{~m}^{3} \mathrm{ha}^{-1}$ of OMWW deriving from pressure extraction method was provided. This is in accordance with Gioffré et al. [114] who reported that OMWW spreading did not affect olive yield. On the contrary Magdich et al. [115] found that the long-term annual spreading of OMWW at three doses (50, 100, and $200 \mathrm{~m}^{3} \mathrm{ha}^{-1}$ year $^{-1}$ ) during 8 successive years influenced the physiological and biochemical behavior and yield of adult olive trees (cv. "Chemlali"). In particular, authors found that olive tree responses were dependent on OMWW dose applied. Effects on leaves gas exchange were positive with doses lower than $100 \mathrm{~m}^{3} \mathrm{ha}^{-1}$ and became negative at higher doses (i.e., $200 \mathrm{~m}^{3} \mathrm{ha}^{-1}$ ).

\section{Conclusions}

To the best of our knowledge, this is the one of few studies where bacterial communities of an olive grove after OMMW treatment were characterized and their evolution over time investigated. Moreover, the changes of main chemical parameters of soil were investigated and correlated to the variations of soil microbial community. The metagenomic approach allowed a wide description of the bacterial communities present in the soil providing both a quality and quantitative characterization. This work has demonstrated that the application of OMWW affected in the first two weeks the $\mathrm{pH}$, salinity, available $\mathrm{P}$, WEOC parameters at both depths. Afterwards all changes were restored, except for the available P. Gram-positive bacteria, particularly the Firmicutes, were the phyla with the lowest tolerance to the addition of OMWW. On the other hand, among the Gram-negative bacteria, Protobacteria were positively correlated to EC, available $\mathrm{P}$, and TEC, suggesting their rapid growth respect to the Gram-positive bacteria and their important role in the $C$ dynamics. Even the microbial analysis suggested that the treatment with OMWW modified in few days the abundances of bacterial taxa in the soil, which are restored along time. The ability of soil to well retain different components could allow to some phyla to try benefit against others for longer periods. As a consequence, the microbial communities could be directionally changed, promoting bacterial phyla that take advantages from components present in OMWW and disadvantaging others, when the treatments are repeated for a long time. Moreover, the application of OMWW did not negatively affect leaf net photosynthesis, the olive tree vegetative activity, yield, and fruits characteristics.

In conclusion, the data reported in the present paper provide positive indications on the long-term use of OMWW as soil amendment. Although the OMWW can be potentially rich in phytotoxic compounds, its long-term use did not affect negatively the chemicalmicrobiological characteristics of the soil, and on the olive tree vegetal-productive activities. The other disposal methods (incineration, ultrafiltration, concentration, etc.) commonly used for the OMWW are generally not capable of reducing the pollutants to the levels set by the law and are expensive for most of the oil mills which are mostly of small size and produce sludge that is difficult to dispose of. Even lagooning, while not requiring large investments, is difficult in practical because it has a very slow biodegradation activity, producing bad smell that spread over large areas.

On the contrary the soil spreading of OMWW can be considered an environmentally friendly practice to recycle this organic material and improve soil fertility, permitting a 
reduction in the use of chemical fertilizers, which are expensive and often can determine pollution phenomena and energy consumption. Although with the dosage imposed by the law $\left(80 \mathrm{~m}^{3} \mathrm{ha}^{-1}\right.$ year $\left.^{-1}\right)$ no toxicity phenomena have been observed, it is prudent not to increase this quantity because in other contexts (e.g., sandy soils) it could have fewer positive results.

Supplementary Materials: The following are available online at https://www.mdpi.com/article/10 .3390/agronomy11122562/s1. Methods S1. DNA purification method modified from Bolano et al. (2001). Figure S1: Principal coordinate analysis (PCoA) of the bacterial communities characterized in different period of OMWW treatment. Figure S2: Volcano plot representation of ANCOM analyses. The $\mathrm{W}$ statistic indicates the value of the statistical test corresponding to the number of times the null hypothesis was rejected for each ASV. ASVs with relative abundance significantly different are evidenced in blue (c98061c433607fe4b2f06fceb61c7458) and red (67465099c7e7995ae38f287944b6094f). Table S1: Alpha-diversity measures of the observed ASV richness, Shannon and Simpson's index for each sample and at each different treatment period. Table S2: Relative abundance description of bacterial communities characterized into OMWW samples.

Author Contributions: Conceptualization: L.R., D.P., S.C.; methodology: L.R., D.P., S.C.; investigation: L.R., D.P., S.C., G.M.; data curation: L.R., D.P., S.C., G.M.; writing—original draft preparation: L.R., D.P., S.C., G.M.; writing—review and editing: E.A., G.G., P.P.; supervision: E.A., G.G., P.P. All authors have read and agreed to the published version of the manuscript.

Funding: This research was funded by the EU Rural Development Plan 2014-2020 of the Umbria Region, Italy (Action 16.1; grant number 84250135484) and by Fondazione CRPG Project "Effetti su agroecosistema e qualità olio della fertirrigazione con reflui oleari e ottimizzazione della tecnica nell'ottica di un'economia circolare" (2017.0217.021).

Institutional Review Board Statement: Not applicable.

Informed Consent Statement: Not applicable.

Data Availability Statement: The data presented in this study are available in the study itself.

Acknowledgments: The authors acknowledge Gina Pero for laboratory analysis and Società agricola Attone (Bevagna-PG, Italy) for making their olive grove available for the experimentation.

Conflicts of Interest: The authors declare no conflict of interest.

\section{References}

1. Nasini, L.; Gigliotti, G.; Balduccini, M.A.; Federici, E.; Cenci, G.; Proietti, P. Effect of solid olive-mill waste amendment on soil fertility and olive (Olea europaea L.) tree activity. Agric. Ecosyst. Environ. 2013, 164, 292-297. [CrossRef]

2. Federici, E.; Massaccesi, L.B.; Pezzolla, D.; Fidati, L.; Montalbani, E.; Proietti, P.; Nasini, L.; Regni, L.; Scargetta, S.; Gigliotti, G. Short-term modifications of soil microbial community structure and soluble organic matter chemical composition following amendment with different solid olive mill waste and their derived composts. Appl. Soil Ecol. 2017, 119, 234-241. [CrossRef]

3. Mechri, B.; Chehab, H.; Attia, F.; Mariem, F.; Braham, M.; Hammami, M. Olive mill wastewater effects on the microbial communities as studied in the field of olive trees by analysis of fatty acid signatures. Eur. J. Soil Biol. 2010, 46, 312-318. [CrossRef]

4. Ouzounidou, G.; Zervakis, G.I.; Gaitis, F. Raw and microbiologically detoxified olive mill waste and their impact on plant growth. Terr. Aquat. Environ. Toxicol. 2010, 4, 21-38.

5. Ntougias, S.; Bourtzis, K.; Tsiamis, G. The microbiology of olive mill wastes. BioMed Res. Int. 2013, 2013, 784591. [CrossRef] [PubMed]

6. Regni, L.; Nasini, L.; Ilarioni, L.; Brunori, A.; Massaccesi, L.; Agnelli, A.; Proietti, P. Long Term Amendment with Fresh and Composted Solid Olive Mill Waste on Olive Grove Affects Carbon Sequestration by Prunings, Fruits, and Soil. Front. Plant Sci. 2017, 7, 2042. [CrossRef] [PubMed]

7. Morillo, J.A.; Antizar-Ladislao, B.; Monteoliva-Sánchez, M.; Ramos-Cormenzana, A.; Russell, N.J. Bioremediation and biovalorisation of olive-mill wastes. Appl. Microbiol. Biotechnol. 2009, 82, 25-39. [CrossRef]

8. Barbera, A.; Maucieri, C.; Cavallaro, V.; Ioppolo, A.; Spagna, G. Effects of spreading olive mill wastewater on soil properties and crops, a review. Agric. Water Manag. 2013, 119, 43-53. [CrossRef]

9. Aviani, I.; Raviv, M.; Hadar, Y.; Saadi, I.; Dag, A.; Ben-Gal, A.; Yermiyahu, U.; Zipori, I.; Laor, Y. Effects of harvest date, irrigation level, cultivar type and fruit water content on olive mill wastewater generated by a laboratory scale 'Abencor' milling system. Bioresour. Technol. 2012, 107, 87-96. [CrossRef]

10. Ammar, E.; Nasri, M.; Medhioub, K. Isolation of Enterobacteria able to degrade simple aromatic compounds from the wastewater from olive oil extraction. World J. Microbiol. Biotechnol. 2005, 21, 253-259. [CrossRef] 
11. Borja, R.; Sánchez, E.; Raposo, F.; Rincón, B.; Jiménez, A.; Martín, A. A study of the natural biodegradation of two-phase olive mill solid waste during its storage in an evaporation pond. Waste Manag. 2006, 26, 477-486. [CrossRef]

12. Jarboui, R.; Sellami, F.; Kharroubi, A.; Gharsallah, N.; Ammar, E. Olive mill wastewater stabilization in open-air ponds: Impact on clay-sandy soil. Bioresour. Technol. 2008, 99, 7699-7708. [CrossRef]

13. Mekki, A.; Dhouib, A.; Sayadi, S. Review: Effects of olive mill wastewater application on soil properties and plants growth. Int. J. Recycl. Org. Waste Agric. 2013, 2, 15-21. [CrossRef]

14. Justino, C.I.L.; Pereira, R.; Freitas, A.C.; Rocha-Santos, T.A.P.; Panteleitchouk, T.S.L.; Duarte, A.C. Olive oil mill wastewaters before and after treatment: A critical review from the ecotoxicological point of view. Ecotoxicology 2011, 21, 615-629. [CrossRef]

15. Belaqziz, M.; El-Abbassi, A.; Lakhal, E.K.; Agrafioti, E.; Galanakis, C.M. Agronomic application of olive mill wastewater: Effects on maize production and soil properties. J. Environ. Manag. 2016, 171, 158-165. [CrossRef] [PubMed]

16. Ayoub, S.; Al-Absi, K.; Al-Shdiefat, S.; Al-Majali, D.; Hijazean, D. Effect of olive mill wastewater land-spreading on soil properties, olive tree performance and oil quality. Sci. Hortic. Amst. 2014, 175, 160-166. [CrossRef]

17. Di Serio, M.; Lanza, B.; Mucciarella, M.; Russi, F.; Iannucci, E.; Marfisi, P.; Madeo, A. Effects of olive mill wastewater spreading on the physico-chemical and microbiological characteristics of soil. Int. Biodeterior. Biodegrad. 2008, 62, 403-407. [CrossRef]

18. Zbakh, H.; El Abbassi, A. Potential use of olive mill wastewater in the preparation of functional beverages: A review. J. Funct. Foods 2012, 4, 53-65. [CrossRef]

19. Chaari, L.; Elloumi, N.; Mseddi, S.; Gargouri, K.; Ben Rouina, B.; Mechichi, T.; Kallel, M. Changes in Soil Macronutrients after a Long-Term Application of Olive Mill Wastewater. J. Agric. Chem. Environ. 2015, 4, 1-13. [CrossRef]

20. Pezzolla, D.; Said-Pullicino, D.; Raggi, L.; Albertini, E.; Gigliotti, G. Short-term Variations in Labile Organic C and Microbial Biomass Activity and Structure After Organic Amendment of Arable Soils. Soil Sci. 2013, 178, 474-485. [CrossRef]

21. Said-Pullicino, D.; Erriquens, F.G.; Gigliotti, G. Changes in the chemical characteristics of water-extractable organic matter during composting and their influence on compost stability and maturity. Bioresour. Technol. 2007, 98, 1822-1831. [CrossRef]

22. Said-Pullicino, D.; Kaiser, K.; Guggenberger, G.; Gigliotti, G. Changes in the chemical composition of water-extractable organic matter during composting: Distribution between stable and labile organic matter pools. Chemosphere 2007, 66, 2166-2176. [CrossRef] [PubMed]

23. Piotrowska, A.; Iamarino, G.; Rao, M.A.; Gianfreda, L. Short-term effects of olive mill waste water (OMW) on chemical and biochemical properties of a semiarid Mediterranean soil. Soil Biol. Biochem. 2006, 38, 600-610. [CrossRef]

24. Di Bene, C.; Pellegrino, E.; Debolini, M.; Silvestri, N.; Bonari, E. Short- and long-term effects of olive mill wastewater land spreading on soil chemical and biological properties. Soil Biol. Biochem. 2013, 56, 21-30. [CrossRef]

25. Mohawesh, O.; Al-Hamaiedeh, H.; Albalasmeh, A.; Qaraleh, S.; Haddadin, M. Effect of Olive Mill Wastewater (OMW) Application on Soil Properties and Wheat Growth Performance Under Rain-Fed Conditions. Water Air Soil Pollut. 2019, 230, 160. [CrossRef]

26. Magdich, S.; Jarboui, R.; Ben Rouina, B.; Boukhris, M.; Ammar, E. A yearly spraying of olive mill wastewater on agricultural soil over six successive years: Impact of different application rates on olive production, phenolic compounds, phytotoxicity and microbial counts. Sci. Total Environ. 2012, 430, 209-216. [CrossRef]

27. Proietti, P.; Federici, E.; Fidati, L.; Scargetta, S.; Massaccesi, L.; Nasini, L.; Regni, L.; Ricci, A.; Cenci, G.; Gigliotti, G. Effects of amendment with oil mill waste and its derived-compost on soil chemical and microbiological characteristics and olive (Olea europaea L.) productivity. Agric. Ecosyst. Environ. 2015, 207, 51-60. [CrossRef]

28. Altieri, R.; Esposto, A. Olive orchard amended with two experimental olive mill wastes mixtures: Effects on soil organic carbon, plant growth and yield. Bioresour. Technol. 2008, 99, 8390-8393. [CrossRef]

29. Roig, A.; Cayuela, M.L.; Sánchez-Monedero, M.A. An overview on olive mill wastes and their valorisation methods. Waste Manag. 2006, 26, 960-969. [CrossRef] [PubMed]

30. Amaral, C.; Lucas, M.S.; Coutinho, J.; Crespí, A.L.; do Rosário Anjos, M.; Pais, C. Microbiological and physicochemical characterization of olive mill wastewaters from a continuous olive mill in Northeastern Portugal. Bioresour. Technol. 2008, 99, 7215-7223. [CrossRef]

31. El Hadrami, A. Physico-chemical Characterization and Effects of Olive Oil Mill Wastewaters Fertirrigation on the Growth of Some Mediterranean Crops. J. Agron. 2004, 3, 247-254. [CrossRef]

32. Ayed, L.; Assas, N.; Sayadi, S.; Hamdi, M. Involvement of lignin peroxidase in the decolourization of black olive mill wastewaters by Geotrichum candidum. Lett. Appl. Microbiol. 2005, 40, 7-11. [CrossRef]

33. Saadi, I.; Laor, Y.; Raviv, M.; Medina, S. Land spreading of olive mill wastewater: Effects on soil microbial activity and potential phytotoxicity. Chemosphere 2007, 66, 75-83. [CrossRef] [PubMed]

34. Karpouzas, D.G.; Rousidou, C.; Papadopoulou, K.K.; Bekris, F.; Zervakis, G.I.; Singh, B.K.; Ehaliotis, C. Effect of continuous olive mill wastewater applications, in the presence and absence of nitrogen fertilization, on the structure of rhizosphere-soil fungal communities. FEMS Microbiol. Ecol. 2009, 70, 388-401. [CrossRef] [PubMed]

35. Kavroulakis, N.; Ntougias, S. Bacterial and $\beta$-proteobacterial diversity in Olea europaea var. mastoidis- and Olea europaea var. koroneiki-generated olive mill wastewaters: Influence of cultivation and harvesting practice on bacterial community structure. World J. Microbiol. Biotechnol. 2010, 27, 57-66. [CrossRef]

36. Rincón, B.; Raposo, F.; Borja, R.; Gonzalez, J.; Portillo, M.; Saiz-Jimenez, C. Performance and microbial communities of a continuous stirred tank anaerobic reactor treating two-phases olive mill solid wastes at low organic loading rates. J. Biotechnol. 2006, 121, 534-543. [CrossRef] 
37. Morillo, J.A.; Aguilera, M.; Antízar-Ladislao, B.; Fuentes, S.; Ramos-Cormenzana, A.; Russell, N.J.; Monteoliva-Sánchez, M. Molecular microbial and chemical investigation of the bioremediation of two-phase olive mill waste using laboratory-scale bioreactors. Appl. Microbiol. Biotechnol. 2008, 79, 309-317. [CrossRef]

38. Tsiamis, G.; Tzagkaraki, G.; Chamalaki, A.; Xypteras, N.; Andersen, G.; Vayenas, D.; Bourtzis, K. Olive-Mill Wastewater Bacterial Communities Display a Cultivar Specific Profile. Curr. Microbiol. 2011, 64, 197-203. [CrossRef] [PubMed]

39. Lakshmanan, V.; Selvaraj, G.; Bais, H.P. Functional Soil Microbiome: Belowground Solutions to an Aboveground Problem. Plant Physiol. 2014, 166, 689-700. [CrossRef]

40. Jansson, J.; Hofmockel, K.S. The soil microbiome-From metagenomics to metaphenomics. Curr. Opin. Microbiol. 2018, 43, 162-168. [CrossRef]

41. Fausto, C.; Mininni, A.N.; Sofo, A.; Crecchio, C.; Scagliola, M.; Dichio, B.; Xiloyannis, C. Olive orchard microbiome: Characterisation of bacterial communities in soil-plant compartments and their comparison between sustainable and conventional soil management systems. Plant Ecol. Divers. 2018, 11, 597-610. [CrossRef]

42. Sofo, A.; Ricciuti, P.; Fausto, C.; Mininni, A.N.; Crecchio, C.; Scagliola, M.; Malerba, A.D.; Xiloyannis, C.; Dichio, B. The metabolic and genetic diversity of soil bacterial communities depends on the soil management system and $\mathrm{C} / \mathrm{N}$ dynamics: The case of sustainable and conventional olive groves. Appl. Soil Ecol. 2019, 137, 21-28. [CrossRef]

43. Mekki, A.; Dhouib, A.; Sayadi, S. Changes in microbial and soil properties following amendment with treated and untreated olive mill wastewater. Microbiol. Res. 2006, 161, 93-101. [CrossRef] [PubMed]

44. Mechri, B.; Echbili, A.; Issaoui, M.; Braham, M.; Ben Elhadj, S.; Hammami, M. Short-term effects in soil microbial community following agronomic application of olive mill wastewaters in a field of olive trees. Appl. Soil Ecol. 2007, 36, 216-223. [CrossRef]

45. Jarboui, R.; Chtourou, M.; Azri, C.; Gharsallah, N.; Ammar, E. Time-dependent evolution of olive mill wastewater sludge organic and inorganic components and resident microbiota in multi-pond evaporation system. Bioresour. Technol. 2010, 101, 5749-5758. [CrossRef]

46. Hentati, O.; Oliveira, V.; Sena, C.; Bouji, M.S.M.; Wali, A.; Ksibi, M. Soil contamination with olive mill wastes negatively affects microbial communities, invertebrates and plants. Ecotoxicology 2016, 25, 1500-1513. [CrossRef]

47. Peikert, B.; Schaumann, G.E.; Bibus, D.; Fischer, J.; Braun, U.; Brunkhardt, J. Effects of olive oil mill wastewater on chemical, microbiological, and physical properties of soil incubated under four different climatic conditions. Biol. Fertil. Soils 2016, 53, 89-102. [CrossRef]

48. Rossi, L.; Regni, L.; Rinaldi, S.; Sdringola, P.; Calisti, R.; Brunori, A.; Dini, F.; Proietti, P. Long-Term Water Footprint Assessment in a Rainfed Olive Tree Grove in the Umbria Region, Italy. Agric. Lond. 2019, 10, 8. [CrossRef]

49. Bacon, J.R.; Hudson, G. A flexible methodology for the characterization of soils: A case study of the heavy metal status of a site at Dornach. Sci. Total Environ. 2001, 264, 153-162. [CrossRef]

50. Tian, G.; Vose, J.M.; Coleman, D.; Geron, C.D.; Walker, J.T. Evaluation of the effectiveness of riparian zone restoration in the southern Appalachians by assessing soil microbial populations. Appl. Soil Ecol. 2004, 26, 63-68. [CrossRef]

51. Nelson, D.W.; Sommers, L.E. Total Carbon, Organic Carbon, and Organic Matter. In Methods of Soil Analysis: Part 3 Chemical Methods; Bigham, J.M., Ed.; SSSA: Madison, WI, USA, 1996; Volume 5, pp. 961-1010.

52. ANPA (Agenzia Nazionale per la Protezione Dell'Ambiente). Metodi di Analisi del Compost. Manuali e Linee Guida 3; ANPA: Roma, Italy, 2001.

53. Carter, M.R.; Gregorich, E.G. (Eds.) Soil Sampling and Methods of Analysis; CRC Press: Boca Raton, FL, USA, 2008.

54. Ciavatta, C.; Govi, M.; Antisari, L.V.; Sequi, P. An enzymatic approach to the determination of the degree of stabilization of organic carbon in fertilizers. Nutr. Cycl. Agroecosyst. 1990, 25, 167-174. [CrossRef]

55. Pent, M.; Põldmaa, K.; Bahram, M. Bacterial Communities in Boreal Forest Mushrooms Are Shaped Both by Soil Parameters and Host Identity. Front. Microbiol. 2017, 8, 836. [CrossRef] [PubMed]

56. Bolano, A.; Stinchi, S.; Preziosi, R.; Bistoni, F.; Allegrucci, M.; Baldelli, F.; Martini, A.; Cardinali, G. Rapid methods to extract DNA and RNA fromCryptococcus neoformans. FEMS Yeast Res. 2001, 1, 221-224. [CrossRef]

57. Klindworth, A.; Pruesse, E.; Schweer, T.; Peplies, J.; Quast, C.; Horn, M.; Glöckner, F.O. Evaluation of general 16S ribosomal RNA gene PCR primers for classical and next-generation sequencing-based diversity studies. Nucleic Acids Res. 2013, 41, e1. [CrossRef]

58. Bolyen, E.; Rideout, J.R.; Dillon, M.R.; Bokulich, N.A.; Abnet, C.C.; Al-Ghalith, G.A.; Alexander, H.; Alm, E.J.; Arumugam, M.; Asnicar, F.; et al. Reproducible, interactive, scalable and extensible microbiome data science using QIIME. Nat. Biotechnol. 2019, 37, 852-857. [CrossRef]

59. Amir, A.; McDonald, D.; Navas-Molina, J.A.; Kopylova, E.; Morton, J.T.; Xu, Z.Z.; Kightley, E.P.; Thompson, L.R.; Hyde, E.R.; Gonzalez, A.; et al. Deblur Rapidly Resolves Single-Nucleotide Community Sequence Patterns. mSystems 2017, 2, e00191-16. [CrossRef] [PubMed]

60. DeSantis, T.Z.; Hugenholtz, P.; Larsen, N.; Rojas, M.; Brodie, E.L.; Keller, K.; Huber, T.; Dalevi, D.; Hu, P.; Andersen, G.L. Greengenes, a Chimera-Checked $16 S$ rRNA Gene Database and Workbench Compatible with ARB. Appl. Environ. Microbiol. 2016, 71, 672-685. [CrossRef]

61. Pedregosa, F.; Varoquaux, G.; Gramfort, A.; Michel, V.; Thirion, B.; Grisel, O.; Vanderplas, J. Scikit-learn: Machine learning in Python. J. Mach. Learn. Res. 2011, 12, 2825-2830.

62. R Core Team. R: A Language and Environment for Statistical Computing; R Foundation for Statistical Computing: Vienna, Austria. Available online: http:/ / www.R-project.org (accessed on 8 December 2021). 
63. McMurdie, P.J.; Holmes, S. phyloseq: An R Package for Reproducible Interactive Analysis and Graphics of Microbiome Census Data. PLoS ONE 2013, 8, e61217. [CrossRef]

64. De Mendiburu, F. Una Herramienta de Analisis Estadistico para la Investigacion Agricola. Master's Thesis, Lima-PERU, Facultad de Economia y Planificacion Departamento Academico de Estadistica e Informatica (UNI-PERU), Universidad Nacional Agraria La Molina, La Molina, Peru, 2009.

65. Oksanen, J. Vegan: An Introduction to Ordination. 2017. Available online: https://cran.r-project.org/web/packages/vegan/ vignettes/intro-vegan.pdf (accessed on 8 December 2021).

66. Weiss, S.; Xu, Z.Z.; Peddada, S.; Amir, A.; Bittinger, K.; Gonzalez, A.; Lozupone, C.; Zaneveld, J.R.; Vázquez-Baeza, Y.; Birmingham, A.; et al. Normalization and microbial differential abundance strategies depend upon data characteristics. Microbiome 2017, 5, 1-18. [CrossRef] [PubMed]

67. Hsieh, T.C.; Ma, K.H.; Chao, A. iNEXT: An R package for rarefaction and extrapolation of species diversity (H ill numbers). Methods Ecol. Evol. 2016, 7, 1451-1456. [CrossRef]

68. Anderson, M.J.; Willis, T.J. Canonical analysis of principal coordinates: A useful method of constrained ordination for ecology. Ecology 2003, 84, 511-525. [CrossRef]

69. Mandal, S.; Van Treuren, W.; White, R.A.; Eggesbø, M.; Knight, R.T.; Peddada, S.D. Analysis of composition of microbiomes: A novel method for studying microbial composition. Microb. Ecol. Health Dis. 2015, 26, 27663. [CrossRef] [PubMed]

70. Lê, S.; Josse, J.; Husson, F. FactoMineR: AnRPackage for Multivariate Analysis. J. Stat. Softw. 2008, 25, 1-18. [CrossRef]

71. Zar, J.H. Multiple repression and correlation. In Biostatistical Analysis; Zar, J.H., Ed.; Prentice-Hall International: Upper Saddle River, NJ, USA, 1996; pp. 407-445.

72. Akaike, H. A New Look at the Statistical Model Identification. In Selected Papers of Hirotugu Akaike; Springer: New York, NY, USA, 1974; pp. 215-222.

73. Venables, W.N.; Ripley, B.D. Modern Applied Statistics with S, 4th ed.; Springer: New York, NY, USA, 2002; ISBN 0-387-95457-0.

74. Legendre, P.; Legendre, L. Numerical Ecology; Elsevier: Amsterdam, The Netherlands, 1998; p. 853.

75. Acland, A.; Agarwala, R.; Barrett, T.; Beck, J.; Benson, D.A.; Bollin, C.; Bolton, E.; Bryant, S.H.; Canese, K.; Church, D.M.; et al. Database resources of the National Center for Biotechnology Information. Nucleic Acids Res. 2014, 42, D7-D17. [CrossRef]

76. Altschul, S.F.; Gish, W.; Miller, W.; Myers, E.W.; Lipman, D.J. Basic local alignment search tool. J. Mol. Biol. 1990, 215, 403-410. [CrossRef]

77. Sierra, J.; Martí, E.; Montserrat, G.; Cruañas, R.; Garau, M. Characterisation and evolution of a soil affected by olive oil mill wastewater disposal. Sci. Total Environ. 2001, 279, 207-214. [CrossRef]

78. Meftah, O.; Guergueb, Z.; Braham, M.; Sayadi, S.; Mekki, A. Long term effects of olive mill wastewaters application on soil properties and phenolic compounds migration under arid climate. Agric. Water Manag. 2019, 212, 119-125. [CrossRef]

79. Mahmoud, M.; Janssen, M.; Haboub, N.; Nassour, A.; Lennartz, B. The impact of olive mill wastewater application on flow and transport properties in soils. Soil Tillage Res. 2010, 107, 36-41. [CrossRef]

80. Rousk, J.; Brookes, P.C.; Bååth, E. Contrasting Soil pH Effects on Fungal and Bacterial Growth Suggest Functional Redundancy in Carbon Mineralization. Appl. Environ. Microbiol. 2009, 75, 1589-1596. [CrossRef] [PubMed]

81. Chu, H.; Fierer, N.; Lauber, C.L.; Caporaso, J.G.; Knight, R.; Grogan, P. Soil bacterial diversity in the Arctic is not fundamentally different from that found in other biomes. Environ. Microbiol. 2010, 12, 2998-3006. [CrossRef] [PubMed]

82. Wei, Z.; Hu, X.; Li, X.; Zhang, Y.; Jiang, L.; Li, J.; Guan, Z.; Cai, Y.; Liao, X. The rhizospheric microbial community structure and diversity of deciduous and evergreen forests in Taihu Lake area, China. PLoS ONE 2017, 12, e0174411. [CrossRef]

83. Pezzolla, D.; Marconi, G.; Turchetti, B.; Zadra, C.; Agnelli, A.; Veronesi, F.; Onofri, A.; Benucci, G.M.N.; Buzzini, P.; Albertini, E.; et al. Influence of exogenous organic matter on prokaryotic and eukaryotic microbiota in an agricultural soil. A multidisciplinary approach. Soil Biol. Biochem. 2015, 82, 9-20. [CrossRef]

84. Marschner, B. Structure and function of the soil microbial community in a long-term fertilizer experiment. Soil Biol. Biochem. 2003, 35, 453-461. [CrossRef]

85. Francioli, D.; Schulz, E.; Lentendu, G.; Wubet, T.; Buscot, F.; Reitz, T. Mineral vs. Organic Amendments: Microbial Community Structure, Activity and Abundance of Agriculturally Relevant Microbes Are Driven by Long-Term Fertilization Strategies. Front. Microbiol. 2016, 7, 1446. [CrossRef]

86. de Gannes, V.; Eudoxie, G.; Hickey, W.J. Prokaryotic successions and diversity in composts as revealed by 454-pyrosequencing. Bioresour. Technol. 2013, 133, 573-580. [CrossRef]

87. Neher, D.A.; Weicht, T.R.; Bates, S.T.; Leff, J.W.; Fierer, N. Changes in Bacterial and Fungal Communities across Compost Recipes, Preparation Methods, and Composting Times. PLoS ONE 2013, 8, e79512. [CrossRef] [PubMed]

88. Storey, S.; Chualain, D.N.; Doyle, O.; Clipson, N.; Doyle, E. Comparison of bacterial succession in green waste composts amended with inorganic fertiliser and wastewater treatment plant sludge. Bioresour. Technol. 2015, 179, 71-77. [CrossRef]

89. Bertin, L.; Colao, M.C.; Ruzzi, M.; Fava, F. Performances and microbial features of a granular activated carbon packed-bed biofilm reactor capable of an efficient anaerobic digestion of olive mill wastewaters. FEMS Microbiol. Ecol. 2004, 48, 413-423. [CrossRef]

90. Bertin, L.; Colao, M.C.; Ruzzi, M.; Marchetti, L.; Fava, F. Performances and microbial features of an aerobic packed-bed biofilm reactor developed to post-treat an olive mill effluent from an anaerobic GAC reactor. Microb. Cell Factories 2006, 5, 16. [CrossRef]

91. Ntougias, S.; Zervakis, G.I.; Ehaliotis, C.; Kavroulakis, N.; Papadopoulou, K.K. Ecophysiology and molecular phylogeny of bacteria isolated from alkaline two-phase olive mill wastes. Res. Microbiol. 2006, 157, 376-385. [CrossRef] [PubMed] 
92. Pozo, C.; Rodelas, B.; Martínez-Toledo, M.V.; Vílchez, R.; González-López, J. Removal of organic load from olive washing water by an aerated submerged biofilter and profiling of the bacterial community involved in the process. J. Microbiol. Biotechnol. 2007, $17,18051300$.

93. Vivas, A.; Moreno, B.; Garcia-Rodriguez, S.; Benitez, E. Assessing the impact of composting and vermicomposting on bacterial community size and structure, and microbial functional diversity of an olive-mill waste. Bioresour. Technol. 2009, 100, 1319-1326. [CrossRef] [PubMed]

94. Rousk, J.; Bååth, E.; Brookes, P.C.; Lauber, C.L.; Lozupone, C.; Caporaso, J.G.; Knight, R.; Fierer, N. Soil bacterial and fungal communities across a pH gradient in an arable soil. ISME J. 2010, 4, 1340-1351. [CrossRef]

95. Blagodatskaya, E.; Blagodatsky, S.; Anderson, T.-H.; Kuzyakov, Y. Priming effects in Chernozem induced by glucose and N in relation to microbial growth strategies. Appl. Soil Ecol. 2007, 37, 95-105. [CrossRef]

96. Fierer, N.; Breitbart, M.; Nulton, J.; Salamon, P.; Lozupone, C.; Jones, R.; Robeson, M.; Edwards, R.; Felts, B.; Rayhawk, S.; et al. Metagenomic and Small-Subunit rRNA Analyses Reveal the Genetic Diversity of Bacteria, Archaea, Fungi, and Viruses in Soil. Appl. Environ. Microbiol. 2007, 73, 7059-7066. [CrossRef] [PubMed]

97. Ullah, A.; Mushtaq, H.; Fahad, S.; Shah, A.; Chaudhary, H.J. Plant growth promoting potential of bacterial endophytes in novel association with Olea ferruginea and Withania coagulans. Microbiology 2017, 86, 119-127. [CrossRef]

98. Kumar, A.; Maurya, B.R.; Raghuwanshi, R.; Meena, V.S.; Islam, M.T. Co-inoculation with Enterobacter and Rhizobacteria on Yield and Nutrient Uptake by Wheat (Triticum aestivum L.) in the Alluvial Soil Under Indo-Gangetic Plain of India. J. Plant Growth Regul. 2017, 36, 608-617. [CrossRef]

99. Bhise, K.K.; Bhagwat, P.K.; Dandge, P.B. Plant Growth-Promoting Characteristics of Salt Tolerant Enterobacter cloacae Strain KBPD and Its Efficacy in Amelioration of Salt Stress in Vigna radiata L. J. Plant Growth Regul. 2016, 36, 215-226. [CrossRef]

100. Zhong, W.; Gu, T.; Wang, W.; Zhang, B.; Lin, X.; Huang, Q.; Shen, W. The effects of mineral fertilizer and organic manure on soil microbial community and diversity. Plant Soil 2010, 326, 511-522. [CrossRef]

101. Lazcano, C.; Gómez-Brandón, M.; Revilla, P.; Domínguez, J. Short-term effects of organic and inorganic fertilizers on soil microbial community structure and function. Biol. Fertil. Soils 2013, 49, 723-733. [CrossRef]

102. Siles, J.; Pascual, J.; González-Menéndez, V.; Sampedro, I.; García-Romera, I.; Bills, G. Short-term dynamics of culturable bacteria in a soil amended with biotransformed dry olive residue. Syst. Appl. Microbiol. 2013, 37, 113-120. [CrossRef] [PubMed]

103. Nemergut, D.R.; Cleveland, C.C.; Wieder, W.; Washenberger, C.L.; Townsend, A.R. Plot-scale manipulations of organic matter inputs to soils correlate with shifts in microbial community composition in a lowland tropical rain forest. Soil Biol. Biochem. 2010, 42, 2153-2160. [CrossRef]

104. Pascault, N.; Ranjard, L.; Kaisermann, A.; Bachar, D.; Christen, R.; Terrat, S.; Mathieu, O.; Lévêque, J.; Mougel, C.; Henault, C.; et al. Stimulation of Different Functional Groups of Bacteria by Various Plant Residues as a Driver of Soil Priming Effect. Ecosystems 2013, 16, 810-822. [CrossRef]

105. Liu, J.J.; Sui, Y.Y.; Yu, Z.H.; Shi, Y.; Chu, H.Y.; Jin, J.; Linu, X.; Wang, G. High throughput sequencing analysis of biogeographical distribution of bacterial communities in the black soils of northeast China. Soil Biol. Biochem. 2014, 70, 113-122. [CrossRef]

106. Li, C.H.; Yan, K.; Tang, L.S.; Jia, Z.J.; Li, Y. Change in deep soil microbial communities due to long-term fertilization. Soil Biol. Biochem. 2014, 75, 264-272. [CrossRef]

107. Karpouzas, D.G.; Ntougias, S.; Iskidou, E.; Rousidou, C.; Papadopoulou, K.K.; Zervakis, G.I.; Ehaliotis, C. Olive mill wastewater affects the structure of soil bacterial communities. Appl. Soil Ecol. 2010, 45, 101-111. [CrossRef]

108. Siles, J.A.; Rachid, C.T.C.C.; Sampedro, I.; García-Romera, I.; Tiedje, J.M. Microbial Diversity of a Mediterranean Soil and Its Changes after Biotransformed Dry Olive Residue Amendment. PLoS ONE 2014, 9, e103035. [CrossRef]

109. Sampedro, I.; Giubilei, M.; Cajthaml, T.; Federici, E.; Federici, F.; Petruccioli, M.; D’Annibale, A. Short-term impact of dry olive mill residue addition to soil on the resident microbiota. Bioresour. Technol. 2009, 100, 6098-6106. [CrossRef]

110. Rousidou, C.; Papadopoulou, K.; Zervakis, G.; Singh, B.K.; Ehaliotis, C.; Karpouzas, D.G. Repeated application of diluted olive mill wastewater induces changes in the structure of the soil microbial community. Eur. J. Soil Biol. 2010, 46, 34-40. [CrossRef]

111. Proietti, P.; Cartechini, A.; Tombesi, A. Influenza delle acque reflue di frantoi oleari su olivi in vaso ed in campo. L'informatore Agrario 1988, 45, 87-91.

112. Chartzoulakis, K.; Psarras, G.; Moutsopoulou, M.; Stefanoudaki, E. Application of olive mill wastewater to a Cretan olive orchard: Effects on soil properties, plant performance and the environment. Agric. Ecosyst. Environ. 2010, 138, 293-298. [CrossRef]

113. Ferri, D.; Convertini, G.; Montemurro, F.; Rinaldi, M.; Rana, G. Olive Wastes Spreading in Southern Italy: Effects on Crops and Soil. In Proceedings of the 12th ISCO Conference, Beijing, China, 26-31 May 2002; pp. 593-600.

114. Gioffré, D.; Cannavò, S.; Smorto, D. Risultati sugli effetti delle acque reflue olearie somministrate con diverse modalità su terreno ulivetato in pieno campo e su piante di olivo allevate in mastello. In Valorizzazione di Acque Reflue e Sottoprodotti Dell'industria Agrumaria e Olearia; Laruffa: Reggio Calabria, Italy, 2004; pp. 81-98.

115. Magdich, S.; Abid, W.; Boukhris, M.; Ben Rouina, B.; Ammar, E. Effects of long-term olive mill wastewater spreading on the physiological and biochemical responses of adult Chemlali olive trees (Olea europaea L.). Ecol. Eng. 2016, 97, 122-129. [CrossRef] 